\title{
Mining Waste and Its Sustainable Management: Advances in Worldwide Research
}

\author{
José A. Aznar-Sánchez * (iD), José J. García-Gómez, Juan F. Velasco-Muñoz iD \\ and Anselmo Carretero-Gómez \\ Department of Economics and Business, Research Centre CAESCG and CIAIMBITAL, University of Almería, \\ 04120 Almería, Spain; josejgg@ual.es (J.J.G.-G.); jfvelasco@ual.es (J.F.V.-M.); acarrete@ual.es (A.C.-G.) \\ * Correspondence: jaznar@ual.es; Tel.: +34-950-015-192
}

Received: 23 May 2018; Accepted: 30 June 2018; Published: 2 July 2018

\begin{abstract}
Growing social awareness of the need to adequately treat mining waste in order to protect the environment has led to an increase in the research in this field. The aim of this study was to analyze the dynamics of the research focused on mining waste and its sustainable management on a worldwide scale from 1988 to 2017. A systematic review and a bibliometric analysis of 3577 articles were completed. The results show that research into mining waste has increased, with studies focusing on waste management accounting for almost $40 \%$ of the total. The most productive journals in this field were Applied Geochemistry and Science of the Total Environment. The five most productive countries were the United States, Canada, Spain, Australia, and China. Works on the sustainable management of mining waste were in the minority, but it is an area of research that has considerable potential given the growing social awareness of the environmental repercussions of mining activities and the demands for increasingly sustainable practices. The findings of this study could prove useful for studies into mine waste, as they depict a global view of this line of research.
\end{abstract}

Keywords: mine waste; management; sustainability; bibliometric analysis; systematic review

\section{Introduction}

Mining activity has considerably increased due to notable population growth and worldwide demand for mineral resources [1]. This increase coincides with a new awareness in which environmental concerns have become a growing challenge for all of the agents within the sector $[2,3]$. The social demand has increased for the sustainable development of all of the activities related to mining, particularly the adequate management of waste products during each phase of the mining process, including prospection and exploration, development, extraction, transport and treatment of product obtained, etc. [4]. The mining process generates a large quantity of residues that must be strategically treated and managed to combine economic efficiency with demands for environmental sustainability. Energy requirements, environmental and human health risks, demands on water resources, and the required technology must all be taken into account [5].

The waste generated by mineral extraction may be solid, tailings, or slurry, with the most common being tailings, waste rock, slag, and tail ends, although in certain circumstances, the vegetation and overburden may also be considered waste [6,7]. To avoid negative effects on the environment, waste is maintained in tailing ponds, dams, or tips, in accordance with the local legislation on waste control treatment that is applicable to each mining area, and on recycling where technically possible [8,9]. In turn, each of these structures may be considered inert when they present no danger to human health or the environment, or dangerous when they cause negative effects to the soil, ground and surface water, vegetation, and even the local fauna and population [10,11]. Danger occurs due to the 
toxicity of the waste (acute, chronic, or extrinsic), flammability, reactivity, corrosivity, etc. In these cases, waste management activities that minimize or annul the dangers are required [12].

Mining activities lead to many negative environmental and socio-economic impacts. Many changes take place in the territory and society, such as: alterations of soil use, ecosystem variations, pollution, water shortages and disturbance of groundwater flows, modifications in the infrastructure networks, unbalanced industrial development, forced resettlement, and changes in the economic structure and local population, among others [13]. In the last few years, some studies have focused on the analysis of mining impacts on soil. First, the ground must be tested for contaminants, and the average levels of these elements must be measured in the various soil levels and sediment to establish the margins of safety [14]. Next, studies must be undertaken to establish the concentration of these trace elements in the mine, understand their capacity to produce acid mine drainage, identify the primary and secondary minerals in the waste, and estimate the mobility of the dangerous elements. Sequential extraction techniques are usually used to determine the environmental risks posed by these trace elements. This indicates the degree of adherence of these elements to the soil, and subsequently how easily they may contaminate the air, water, and food chain $[15,16]$.

Analyses were undertaken of the dispersion of contaminating elements in residues and the structural stability of the deposits of these elements. Studies of human bioaccessibility [17], estimates of enrichment factor (EF), and geoaccumulation index (Igeo) are also common $[18,19]$. Sediment quality guidelines (SQGs) [20] have been introduced, and ecotoxicological risks were evaluated. The risks of the mobility of trace elements to surface and ground water were also evaluated through sediments [21].

Mineral deposits have traditionally been sealed off, although the traditionally used techniques have not been environmentally optimal [22]. Mine waste management systems recommend a geographic description of the residue and its mobility, a revision of the biogenetic and mineral dismantling of sulfide-based residue, a study of jarosite formation and soluble iron sulfates, monitoring the weathering of slag, an analysis of oxidation on the marine floor, the use of wetlands to immobilize trace elements, and the use of microorganisms to reduce the reactivity of mine residues [23].

Although mineral waste management has traditionally been based on the linear economy, the current challenge is to apply the possibilities presented by a circular economy to this problem, so that society changes its fundamentally negative perception of the sector. Recently, concentrations of graphite have been used to reduce tin mine foundry slag. Cement filling processes using superfine tailings have also been used to control sink holes in underground mining. New methods of transporting cement to fill tubes have been introduced, as has the reuse of residues in different geo-engineering applications. The recycling of leaching residue and new tailings procedures have been aimed at deep sea mining [24].

Mining waste management includes the characterization and remediation of residues. The state-of-the-art proposes new methods such as the use of mapping to determine the extent of wastes, the use of hyperspectral instruments [25], the mobility of sediments containing toxic residues [26], the mitigation of toxic metals spread in redox areas [27], the use of biochemical and mineral dissolution processes in sulfurous tailings [28], the dilution of tailings products, and the geochemical and mineral elimination of submarine tailings [29]. Other remediation systems include the use of heat to volatilize toxic components, and the use of microorganisms to reduce the reactivity and toxicity [30].

The potential environmental threat of waste generated by mining, along with an increasing societal awareness of the need to adequately treat mining waste, have led to the increased importance of this line of research. Nevertheless, no analysis of the developments in this research area has been completed as of late. This study aimed to fill that gap by analyzing the dynamics of the research into mining waste and its sustainable management since 1988 on a worldwide scale. The results may prove interesting for researchers of mining waste by offering a global view of the dynamics of this line of research. 


\section{Methodology}

We analyzed two parameters to achieve our intended aim: a quantitative analysis using bibliometry, and a systematic, qualitative revision.

\subsection{Bibliometric Method}

The bibliometric analysis was first introduced by Garfield in the mid-20 ${ }^{\text {th }}$ century [31]. The main objective of this methodology is to identify, organize, and analyze the main components within a specific research field $[32,33]$. Since then, the method has been applied to areas such as engineering, biology, energy, medicine, and administration [34]. Over the last few decades, it has contributed to the review of scientific knowledge. Bibliometry is used to study the evolution and research trends of a topic. Through some statistical and mathematic analyzing tools, the publication relevance within a specific field can be assessed [35]. It also enables identifying the most productive authors, institutions, and countries so that the main researchers of a field can be stated [36].

Moreover, the use of mapping tools enables the identification of collaboration areas between some actors [37]. Thanks to these tools, the bibliographic information of a database can be shown, as well as main research trends [38,39]. Links between authors of different subject areas, institutions and countries can be viewed graphically. This application has been very useful and relevant in areas where international collaboration is essential, as is the case for the mineral sector [40].

Traditionally, co-occurrence analysis, co-quotation, and bibliographic coupling have been the main bibliometric approaches. They have been applied to database metadata according to the year of document publication, theme categories of classification, and obtained quotations of the works and keywords [41]. Currently, the traditional bibliometric methods have given way to new applications: viewing tools and information through text extraction techniques and data mining [42]; techniques of overlaying maps and variable associations [43]; the development of analysis frames to assess innovation [44]; tool developments based on routine types of automatized software [31,41]; and methods to identify and view evolution ways of scientific topics within a time segment [45]. In order to achieve the main goals of our work, a traditional approach based on co-occurrence has been considered best suited, since a general character is pursued. Furthermore, current processing and mapping tools have been applied due to their reliability [43].

Durieux and Gevenois defined three types of indicators when applying bibliometric analysis [46]. These are divided up into: (i) quantity indicators referring to productivity and counting; (ii) qualitative indicators regarding publication impact; and (iii) structural indicators that measure established links between agents. These three types of indicators have been taken into account in this paper. In this way, counting has been used to measure the productivity of authors, journals, institutions, and countries. The quotation number, H-index, and Scopus Journal Ranking (SJR) impact factor, have been used to measure impact. Network maps have been generated to view international links between different actors and analyze hotspots trends in this study field [47].

Obtained results through this type of analysis are very useful for many users. The evolution representation of the main research lines, identification of the most productive and relevant agents, and recognition of future trends are very helpful for junior and senior researchers of a specific research field [42]. Information compilations on new technologies and innovations in rapidly evolving areas mean new investment options for analysts and business agents [44]. Moreover, data on the hottest topics, such as material management, environmental protection, natural resources, and climate change are of particular interest in the decision-making processes from a business and administration point of view.

\subsection{Data and Processing}

The majority of bibliometric analyses use the Scopus data base, as it is considered the largest repository of peer-reviewed literature, it is easily accessible, provides different tools for viewing and 
analyzing publications, and allows data to be downloaded in different formats for processing by software [48].

Currently, there is a debate about the comparability and stability of the gained statistical data based on the two main databases: Web of Science (WoS) and Scopus [49]. Some studies have attempted to answer the question of which database is more adequate to be used for a bibliometric work. It has been proven that Scopus has more indexed journals than WoS [50]. It has also been demonstrated that only the $54 \%$ of the indexed publications in Scopus are comprised in WoS, while $84 \%$ of the WoS titles are indexed in Scopus [51]. The Google Scholar database has not been taken into account, since it has some limitations. Some studies compared the utility of diverse databases to Google Scholar when reviewing literature. Borrett et al. [52] pointed out that Google Scholar includes a greater quantity of non-relevant variables such as help files. Therefore, cleaning the data up requires more effort. Wildgaard [53] argued that Google Scholar includes a great number of non-peer reviewed articles, which generally implies publications with a low quality level. Ştirbu et al. [54] concluded that result processing and classification require a higher effort when using Google Scholar due to its total data amount and limited functioning. For these reasons, Scopus was chosen to perform the bibliometric analysis in this study. Many recent publications have used Scopus to perform bibliometric studies: Judd [55]; Feng, Zhu, and Lai [56]; Mugomeri et al. [57]; Mateo-Sanguino [58], and Kokol, Blazun-Vosner, and Zeleznik [59].

To study the various topics in our research, including mining waste, mining waste management, and the sustainable management of mining waste, we performed a descending search. This kind of search means first selecting a sample of a wider general topic, and subsequently, more restricted searches of the sample are conducted until a specific topic is defined. The main reason for this procedure is to compare the relevance of a specific topic with a broader research field. Initially, a search was performed using the parameters [TITLE-ABS-KEY ("mine waste")], with the aim of covering all of the works related to mining waste. The time scale of the sample was established between 1988-2017. As non-original publications undergo a less rigorous peer-review process, are less available, and may present duplicate information, these were excluded from our sample [60]. The resulting final sample totaled 3577 articles and reviews. A second search using the parameters: [TITLE-ABS-KEY ("mine waste") AND TITLE-ABS-KEY ("reprocessing" OR "reuse" OR "revalorization" OR "repositation" OR "re-using" OR "recycling" OR "remediation" OR "treatment" OR "stabilization" OR "valorization" OR "integrated management")] was undertaken to study the research into mining waste management. Different search terms were tested before reaching the final sample. Various parameters were included, and some of them were finally removed, such as "management", since they introduced a high noise level in the article sample. We applied the same restrictions as the initial search, obtaining a sample of 1092 articles. Finally, to analyze works on the sustainable management of mining waste, a third search was completed that included the following parameters: [TITLE-ABS-KEY ("mine waste") AND TITLE-ABS-KEY ("reprocessing" OR "reuse" OR "revalorization" OR "repositation" OR "re-using" OR "recycling" OR "remediation" OR "treatment" OR "stabilization" OR "valorization" OR "integrated management") AND TITLE-ABS-KEY ("sustainable" OR "sustainability")]. The result was a sample of 59 published articles.

To study the characteristics of the research in these three areas, the selected variables were: the year of publication, publishing journals, authors, institutions, and countries of author affiliation, and keywords. Once data were downloaded in two formats (RIS and csv), the first task to be undertaken was the depuration of information. Later on, data analysis and processing took place. Excel (version 2016) and SciMAT (v1.1.04) were the used software tools. VOSviewer was applied to analyze the links between different authors and keywords, as well as create the corresponding network maps. This software was chosen due to its suitability and frequent use in these kinds of works. Finally, the study of keywords was used to analyze the evolution of research trends and identify future ones. Figure 1 summarizes the followed methodology. 


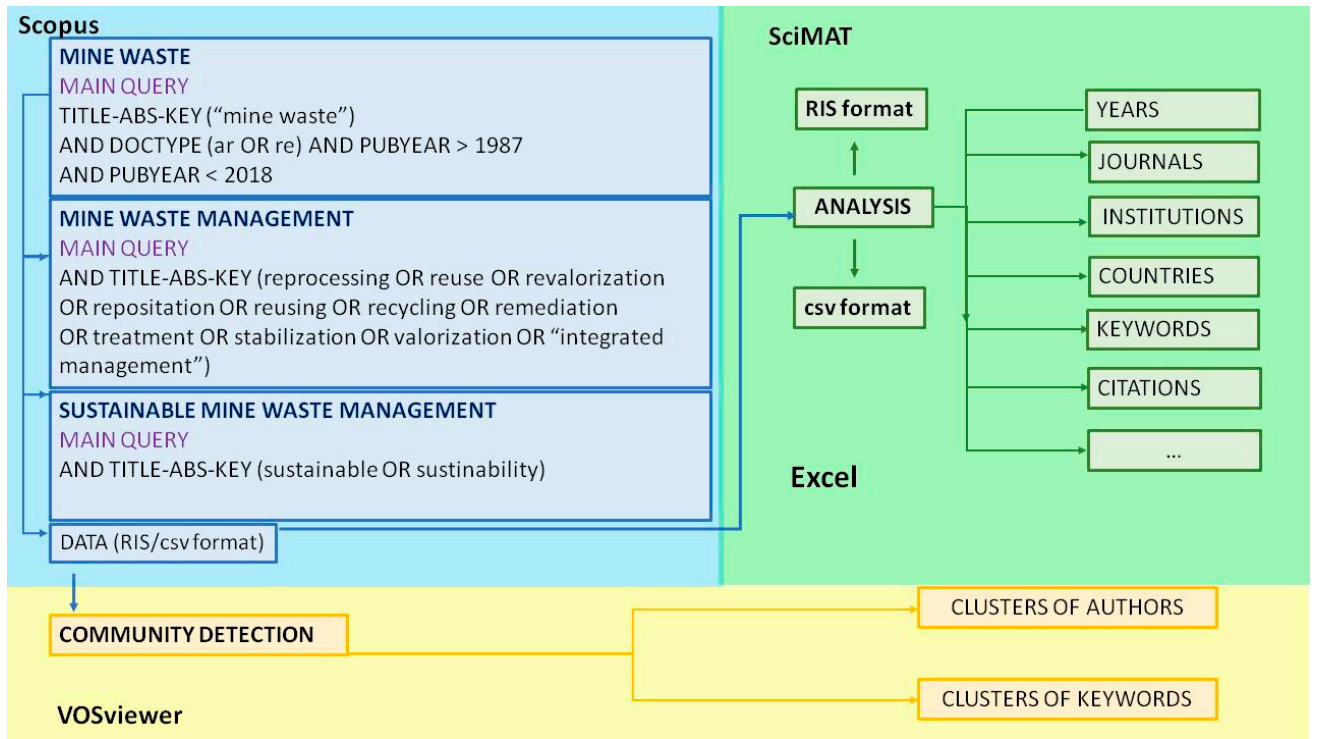

Figure 1. Methodology flow diagram.

\section{Results and Discussion}

\subsection{Mine Waste}

Table 1 shows the evolution of the main variables in research into mine waste (MW) on a global scale from 1988 to 2017 . The number of articles published on this subject (A) increased notably from 14 in 1988 to 279 in 2017. This trend indicates that research into MW has increased in importance, culminating in the maximum number of articles published in 2017. The comparison between the total growth of articles on MW and the total growth of articles within all of the disciplines would be highly interesting, but unfortunately, it was not possible to achieve these data under the current research framework. The remaining variables in Table 1 show a similar growing trend. The number of authors in this field (AU) grew from 28 in 1988 to 1221 in 2017. The number of references (NR) increased exponentially from 86 to 11,323. The number of journals $(\mathrm{J})$ also increased during this period, from 13 in 1988 to 153 in 2017. The internationalization of the field is reflected in the number of countries (C), which increased from four in 1988 to 51 in 2017. The total number of cited articles (TC) on MW was three in 1989, increasing to 7413 citations in 2017. The number of citations per article increased from 0.10 in 1989 to 16.89 in 2017.

Table 1. Major characteristics of the articles published on mine waste (MW).

\begin{tabular}{cccccccc}
\hline Year & A & AU & NR & J & C & TC & CTC/CA \\
\hline 1988 & 14 & 28 & 86 & 13 & 4 & 0 & 0.00 \\
1989 & 15 & 31 & 217 & 12 & 7 & 3 & 0.10 \\
1990 & 18 & 40 & 248 & 13 & 4 & 10 & 0.28 \\
1991 & 21 & 45 & 465 & 19 & 7 & 18 & 0.46 \\
1992 & 8 & 30 & 134 & 7 & 4 & 24 & 0.72 \\
1993 & 26 & 60 & 343 & 24 & 6 & 35 & 0.88 \\
1994 & 22 & 59 & 652 & 19 & 9 & 52 & 1.15 \\
1995 & 32 & 79 & 478 & 30 & 10 & 80 & 1.42 \\
1996 & 38 & 99 & 1012 & 30 & 14 & 122 & 1.77 \\
1997 & 42 & 105 & 905 & 32 & 14 & 166 & 2.16 \\
1998 & 79 & 193 & 1752 & 55 & 26 & 204 & 2.27 \\
1999 & 98 & 293 & 2387 & 54 & 19 & 322 & 2.51 \\
2000 & 108 & 307 & 2596 & 65 & 25 & 370 & 2.70 \\
2001 & 107 & 304 & 2709 & 68 & 30 & 463 & 2.98 \\
\hline
\end{tabular}


Table 1. Cont

\begin{tabular}{cccccccc}
\hline Year & A & AU & NR & J & C & TC & CTC/CA \\
\hline 2002 & 126 & 395 & 2983 & 73 & 33 & 664 & 3.36 \\
2003 & 129 & 387 & 3039 & 82 & 35 & 965 & 3.96 \\
2004 & 137 & 382 & 4292 & 77 & 32 & 1020 & 4.43 \\
2005 & 159 & 521 & 4796 & 91 & 38 & 1465 & 5.07 \\
2006 & 127 & 436 & 4194 & 83 & 38 & 1853 & 6.00 \\
2007 & 165 & 559 & 5147 & 97 & 41 & 2197 & 6.82 \\
2008 & 161 & 513 & 4835 & 101 & 44 & 2678 & 7.79 \\
2009 & 172 & 572 & 5633 & 97 & 43 & 3162 & 8.80 \\
2010 & 168 & 578 & 5901 & 99 & 44 & 3536 & 9.84 \\
2011 & 205 & 714 & 6944 & 105 & 47 & 4249 & 10.87 \\
2012 & 177 & 648 & 6166 & 103 & 50 & 4467 & 11.95 \\
2013 & 233 & 797 & 9007 & 127 & 50 & 5183 & 12.88 \\
2014 & 230 & 863 & 9384 & 129 & 48 & 6087 & 13.98 \\
2015 & 226 & 872 & 9086 & 122 & 52 & 6352 & 15.03 \\
2016 & 255 & 1007 & 10,779 & 126 & 51 & 7245 & 16.07 \\
2017 & 279 & 1221 & 11,323 & 153 & 51 & 7413 & 16.89 \\
\hline
\end{tabular}

A: annual number of articles; AU: annual number of authors; NR: total number of references for all of the articles; $\mathrm{J}$ : annual number of journals; C: annual number of countries; TC: annual number of citations for all articles; CTC/CA: annual total citations per cumulative article.

Figure 2 shows the evolution of the principle subjects under which Scopus classifies articles on MW. Note that one article may be simultaneously included in more than one category. During the period studied, $58.6 \%$ of published articles were classified under the Environmental Sciences category, 47.2\% were in Earth and Planetary Sciences, $16.4 \%$ were in Agricultural and Biological Sciences, $8 \%$ were in Engineering, and 7\% were in Chemistry. These were followed by the categories of Materials Science, Medicine, Social Sciences, Pharmacology, Toxicology, Pharmaceutics, and Energy, but none accounted for $4 \%$ of the total of articles. Since the beginning of the analyzed period, Environmental Science and Earth and Planetary Sciences have been the principle categories. However, since 2006, Environmental Science has become the leading discipline in this area, which indicates that MW research is being principally studied from an environmental perspective.

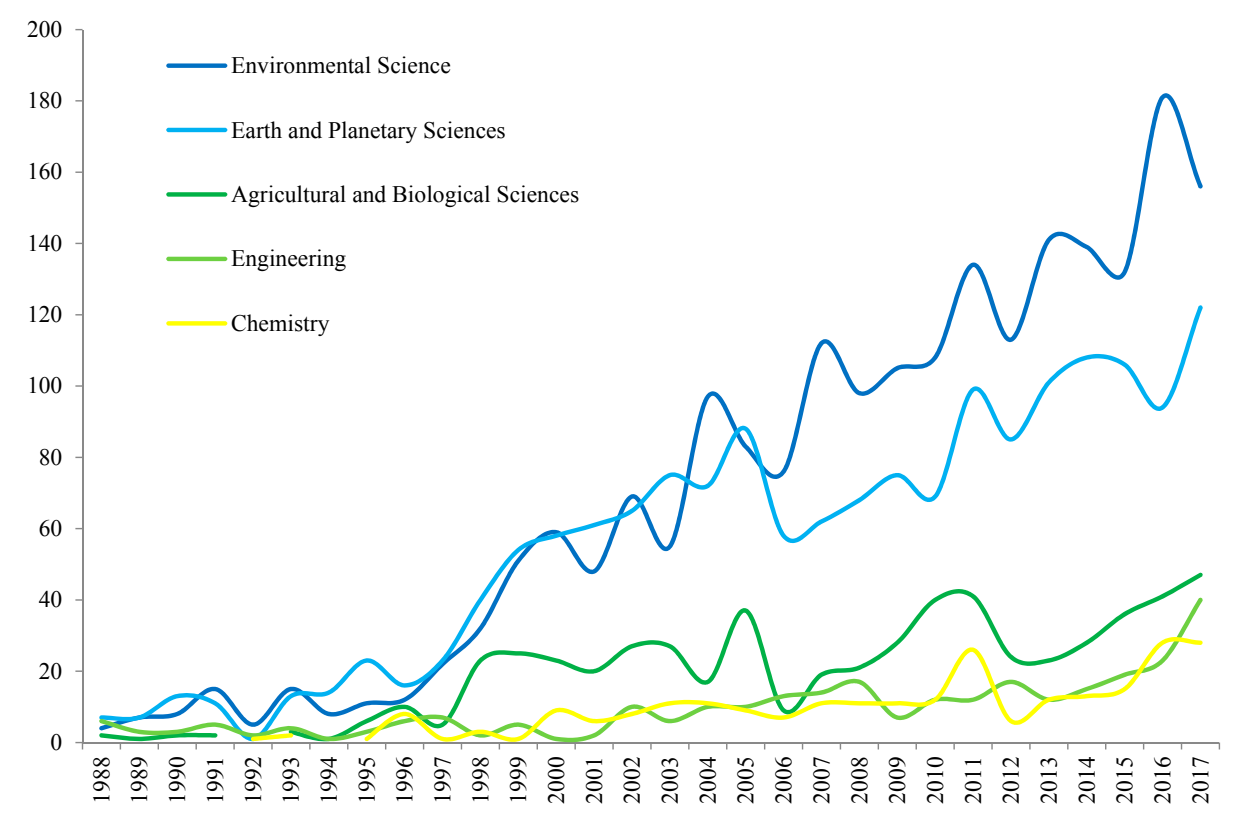

Figure 2. Trend in the subject categories of MW articles published from 1988 to 2017. 
Table 2 shows the 10 journals with the most publications on MW. This group is entirely made up of European journals, specifically British, Dutch, and German journals, with the exception of one Iranian publication. These journals publish $28 \%$ of all of the articles in the field, indicating no great concentration of publication in this area. In the first column, we can see the total number of articles published by each journal along the whole period. Moreover, the evolution of the article number per journal is shown during the three 10-year periods, into which the studied time was divided up. Applied Geochemistry was the most productive journal on this subject from 1988 to 2017, with 155 articles, followed by Science of the Total Environment with 130 articles, the Journal of Geochemical Exploration with 109 articles, and Environmental Earth Sciences with 88 articles. Environmental Earth Sciences was established in 2009 under that name; however, it was previously published under the name of Environmental Geology. This journal occupied the first position in terms of the number of articles published from 1997 to 2009, the year in which it changed its name. From this date, Applied Geochemistry took the first position. During the sub-period of 2008-2017, Environmental Earth Sciences established itself once again in first position. Both appear separately in the fourth and fifth position of the most productive journals, but if the publications were totaled, this journal would take first position with 172 articles and a total of 2875 citations.

Journals with a greater SJR index were: Environmental Pollution with 1.786, the Journal of Hazardous Materials with 1.727, and Science of the Total Environment with 1.621. Applied Geochemistry was the most cited journal, followed by Science of the Total Environment, Environmental Science and Technology, and Chemosphere. However, considering the average number of citations per article, Environmental Science and Technology was the journal with the greatest impact, with a total of 48.8 citations per article. Chemosphere took second position with 44.2 citations per article, and Environmental Pollution was in third place with 37.1 citations per article. This journal had the greatest record within the top 10, since it first published an article on this subject in 1989. Notably, the journals in the top 10 are of the highest quality; they all appear in the first two quartiles of the Scopus classification.

Table 3 shows the 10 most productive countries in the publication of articles on MW. The United States led the group, followed by Canada, Spain, Australia, and China. The number of articles published per million inhabitants (APC) is also shown in this table. This variable is led by Canada with 13.75 articles per capita, followed by Australia with 12.47, Portugal with 10.07, and Spain with 7.29. The United States placed first in the total number of citations, followed by Canada, Spain, and the United Kingdom. However, considering the average number of citations per article, the United Kingdom placed first with 29 citations per article, followed by the United States with 22.3, Spain with 21.4, Portugal with 19.2, and Canada with 18.1. Figure 3 shows the elevated correlation existing between the $\mathrm{H}$ index and number of articles published by each country. 
Table 2. Top 10 most productive journals for MW research.

\begin{tabular}{|c|c|c|c|c|c|c|c|c|c|c|}
\hline \multirow{2}{*}{ Journal } & \multirow{2}{*}{$\mathbf{A}$} & \multirow{2}{*}{ SJR } & \multirow{2}{*}{ H Index } & \multirow{2}{*}{$\mathrm{C}$} & \multirow{2}{*}{ TC } & \multirow{2}{*}{ TC/A } & \multirow{2}{*}{ 1st A } & \multicolumn{3}{|c|}{ R (A) } \\
\hline & & & & & & & & 1988-1997 & 1998-2007 & 2008-2017 \\
\hline Applied Geochemistry & 155 & 1.019 (Q1) & 41 & UK & 4840 & 31.2 & 1991 & $12(3)$ & $2(62)$ & $1(90)$ \\
\hline Science of the Total Environment & 130 & $1.621(\mathrm{Q} 1)$ & 37 & Netherlands & 4289 & 33.0 & 1997 & $3(6)$ & $3(44)$ & $3(84)$ \\
\hline Journal of Geochemical Exploration & 109 & 1.047 (Q1) & 28 & Netherlands & 2635 & 24.2 & 1995 & $5(5)$ & $5(31)$ & $4(73)$ \\
\hline Environmental Earth Sciences & 88 & $0.574(\mathrm{Q} 2)$ & 14 & Germany & 544 & 6.2 & 2009 & 0 & 0 & $2(88)$ \\
\hline Environmental Geology & 84 & ND & 31 & Germany & 2331 & 27.8 & 1993 & $1(7)$ & $1(67)$ & $33(10)$ \\
\hline Water Air and Soil Pollution & 69 & $0.578(\mathrm{Q} 2)$ & 20 & Netherlands & 1120 & 16.2 & 1991 & $12(3)$ & $9(27)$ & $9(39)$ \\
\hline Journal of Hazardous Materials & 68 & $1.727(\mathrm{Q} 1)$ & 25 & Netherlands & 1717 & 25.3 & 1995 & 37 (1) & $16(12)$ & $5(55)$ \\
\hline Chemosphere & 67 & $1.417(\mathrm{Q} 1)$ & 29 & UK & 2962 & 44.2 & 2000 & 0 & $11(20)$ & $7(47)$ \\
\hline Environmental Science and Technology & 67 & $0.575(\mathrm{Q} 2)$ & 31 & Iran & 3270 & 48.8 & 1992 & $3(6)$ & $4(32)$ & $12(29)$ \\
\hline Environmental Pollution & 57 & $1.786(\mathrm{Q} 1)$ & 27 & UK & 2111 & 37.0 & 1989 & $1(7)$ & $7(28)$ & $17(22)$ \\
\hline Environmental Earth Sciences* & 172 & $0.574(\mathrm{Q} 2)$ & 31 & Germany & 2875 & 16.7 & 1993 & $1(7)$ & $1(67)$ & $1(98)$ \\
\hline
\end{tabular}

research by journal; R: ranking position; UK: United Kingdom. 
Table 3. Most productive countries in MW research.

\begin{tabular}{|c|c|c|c|c|c|c|c|}
\hline \multirow{2}{*}{ Country } & \multirow{2}{*}{ A } & \multirow{2}{*}{ APC } & \multirow{2}{*}{ TC } & \multirow{2}{*}{ TC/A } & \multicolumn{3}{|c|}{$\mathbf{R}(\mathrm{A})$} \\
\hline & & & & & 1988-1997 & 1998-2007 & 2008-2017 \\
\hline United States & 613 & 1.897 & 13,646 & 22.3 & $1(62)$ & $1(248)$ & $1(303)$ \\
\hline Canada & 499 & 13.752 & 9050 & 18.1 & $3(21)$ & $2(205)$ & $2(273)$ \\
\hline Spain & 339 & 7.299 & 7247 & 21.4 & $8(3)$ & $5(99)$ & $3(237)$ \\
\hline Australia & 301 & 12.476 & 4113 & 13.7 & $4(17)$ & $5(99)$ & $5(185)$ \\
\hline China & 280 & 0.203 & 4364 & 15.6 & $14(1)$ & $7(62)$ & $4(217)$ \\
\hline United Kingdom & 241 & 3.672 & 6977 & 29.0 & $2(32)$ & $3(113)$ & $7(96)$ \\
\hline Germany & 187 & 2.262 & 3191 & 17.1 & $6(9)$ & $4(105)$ & $10(73)$ \\
\hline India & 170 & 0.128 & 1492 & 8.8 & $8(3)$ & $8(61)$ & $6(106)$ \\
\hline Portugal & 104 & 10.073 & 1996 & 19.2 & 0 & $21(16)$ & $8(88)$ \\
\hline Poland & 103 & 2.714 & 935 & 9.1 & $8(3)$ & $13(22)$ & $9(78)$ \\
\hline
\end{tabular}

A: annual number of total articles; APC: number of articles per 1 mill. inhabitants; TC: annual number of citations for all articles; TC/A: number of citations by article; R: ranking position.

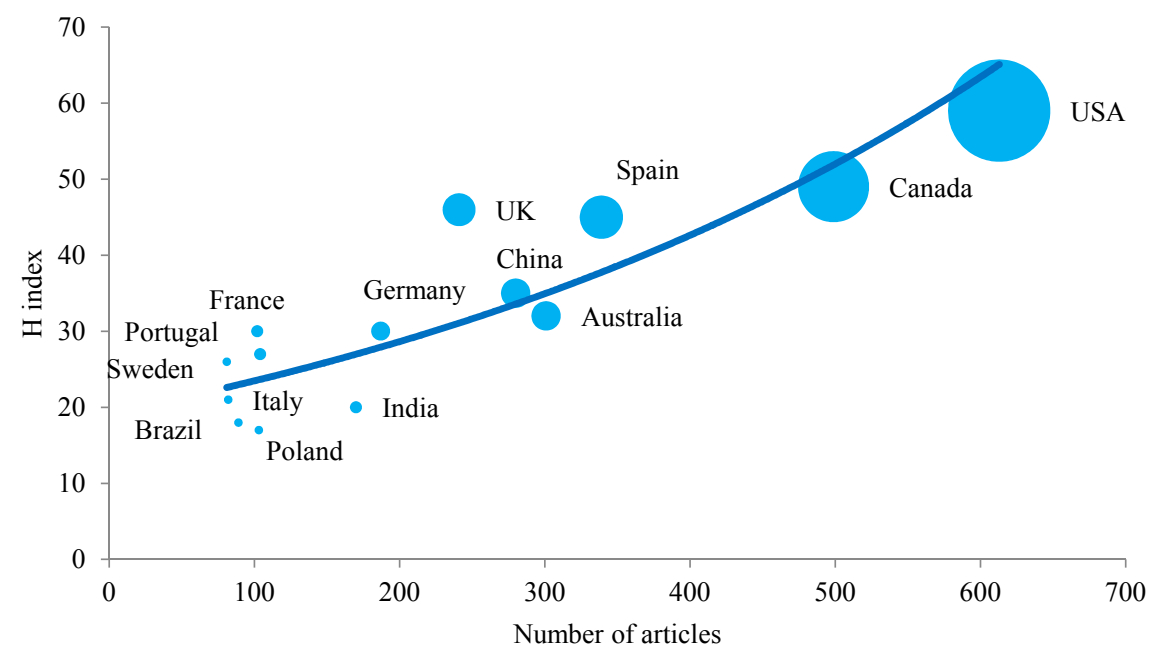

Figure 3. Correlation between $\mathrm{H}$ index and the number of articles by country in MW research.

Table 4 indicates the different variables related to the international collaboration between the group of the 10 most productive countries on the subject of MW. The United Kingdom had the largest percentage of articles produced in collaboration with other countries, with $46.9 \%$ of the total. The United States, Australia, Spain, Canada, and Germany were its main collaborators. These were followed by Germany with $42.8 \%$, Portugal with $40.4 \%$, and Australia with $38.9 \%$ of the total. The United Kingdom was also the country with the greatest number of collaborators, with 46 associates, followed by the United States with 45, and Australia with 38. The United States stands out as the principle collaborator among the remaining top 10 countries, being the foremost collaborator of these five countries: Canada, China, the United Kingdom (UK), Germany, and India. This table also shows the average number of citations (TC/A) per article produced in international collaboration (IC), and those produced without collaboration (NIC), for each country. The number of average citations per article, in every country, was greater with international collaboration, except in the case of the United States, Spain, and Portugal. 
Table 4. International collaboration between the most productive countries in MW research.

\begin{tabular}{|c|c|c|c|c|c|}
\hline \multirow{2}{*}{ Country } & \multirow{2}{*}{ IC (\%) } & \multirow{2}{*}{ NC } & \multirow{2}{*}{ Main Collaborators } & \multicolumn{2}{|c|}{ TC/A } \\
\hline & & & & IC & NIC \\
\hline United States & 31.81 & 45 & Canada, United Kingdom, China, Spain, Australia & 21.4 & 22.7 \\
\hline Canada & 24.05 & 34 & $\begin{array}{l}\text { United States, Australia, Morocco, } \\
\text { United Kingdom, Germany }\end{array}$ & 19.8 & 17.6 \\
\hline Spain & 37.46 & 30 & $\begin{array}{l}\text { Portugal, United States, United Kingdom, } \\
\text { Germany, Netherlands }\end{array}$ & 20.3 & 22.0 \\
\hline Australia & 38.87 & 38 & $\begin{array}{l}\text { Canada, United Kingdom, China, } \\
\text { United States, Germany }\end{array}$ & 18.7 & 10.5 \\
\hline China & 26.07 & 29 & $\begin{array}{l}\text { United States, Australia, Canada, } \\
\text { United Kingdom, Norway }\end{array}$ & 25.4 & 12.1 \\
\hline $\begin{array}{l}\text { United } \\
\text { Kingdom }\end{array}$ & 46.89 & 46 & United States, Australia, Spain, Canada, Germany & 31.3 & 26.9 \\
\hline Germany & 42.78 & 37 & United States, Spain, Australia, Canada, France & 18.7 & 15.8 \\
\hline India & 18.82 & 22 & $\begin{array}{c}\text { United States, Australia, United Kingdom, China, } \\
\text { Russian Federation }\end{array}$ & 11.2 & 8.2 \\
\hline Portugal & 40.38 & 19 & Spain, Australia, Brazil, Tunisia, United States & 17.3 & 20.5 \\
\hline Poland & 16.50 & 24 & $\begin{array}{l}\text { Czech Republic, Netherlands, United States, } \\
\text { China, Germany }\end{array}$ & 13.1 & 8.3 \\
\hline
\end{tabular}

IC: international collaborations; NC: total number of international collaborators; TC/A: total citations per article; NIC: no international collaborations.

The principle characteristics of the institutions with the largest number of publications on MW are displayed in Table 5. Half of these were found in Canada, with the remainder in Spain, China, Australia, and the United States. Canada's University of British Columbia was the institution with the greatest number of articles published, followed by the Chinese Academy of Sciences, the University of Queensland, the United States Geological Survey, and Western University in Canada. The University of Waterloo (Canada) had the largest number of cited publications, followed by the University of British Columbia, the Chinese Academy of Sciences, and the United States Geological Survey. The University of Waterloo also took first position in terms of the average number of citations per article with 37.7, followed by Spain's National Research Council with 27.2, the United States Geological Survey with 24.5, and Western University with 19.3. Spanish institutions were those with the largest percentage of research completed with international collaboration.

Table 5. Most productive institutions in MW research.

\begin{tabular}{|c|c|c|c|c|c|c|c|c|}
\hline \multirow{2}{*}{ Institution } & \multirow{2}{*}{$\mathrm{C}$} & \multirow{2}{*}{ A } & \multirow{2}{*}{ TC } & \multirow{2}{*}{ TC/A } & \multirow{2}{*}{ H Index * } & \multirow{2}{*}{ IC (\%) } & \multicolumn{2}{|c|}{ TC/A } \\
\hline & & & & & & & IC & NIC \\
\hline The University of British Columbia & Canada & 79 & 1417 & 17.9 & 23 & 25.32 & 11.1 & 20.3 \\
\hline Chinese Academy of Sciences & China & 75 & 1412 & 18.8 & 20 & 29.33 & 22.2 & 17.4 \\
\hline University of Queensland & Australia & 55 & 495 & 9.0 & 12 & 25.45 & 14.1 & 7.2 \\
\hline United States Geological Survey & USA & 54 & 1325 & 24.5 & 20 & 22.22 & 21.1 & 25.5 \\
\hline Western University & Canada & 51 & 985 & 19.3 & 17 & 11.76 & 19.8 & 19.2 \\
\hline Universidad Politecnica de Cartagena & Spain & 47 & 867 & 18.4 & 17 & 42.55 & 24.6 & 13.9 \\
\hline Consejo Superior de Investigaciones Científicas & Spain & 46 & 1250 & 27.2 & 19 & 41.30 & 19.3 & 32.7 \\
\hline University of Saskatchewan & Canada & 45 & 731 & 16.2 & 15 & 22.22 & 16.5 & 16.2 \\
\hline Universite du Quebec en Abitibi-Temiscamingue & Canada & 43 & 455 & 10.6 & 12 & 34.88 & 11.7 & 10.0 \\
\hline University of Waterloo & Canada & 41 & 1546 & 37.7 & 21 & 26.83 & 28.8 & 41.0 \\
\hline
\end{tabular}

* Only sample items. C: country; A: annual number of total articles; TC: annual number of citations in total articles;

TC/A: number of citations by article; IC: international collaborations; NIC: no international collaborations. 
Table 6 shows the authors with the largest number of MW articles. The four most prolific authors were affiliated with Canadian institutions. David Blowes of the University of Waterloo was the most seasoned of the ranking with a paper from 1994. He was the most cited, with a total of 1394 citations and the highest $\mathrm{H}$ index (20). Ernest K. Yanful of Western University had 481 citations and an $\mathrm{H}$ index of 14. Following this were Mostafa Benzaazoua and Bruno Bussière of the Université du Quebec. The most recent author to join the ranks was R. Hakkou of the University Cadi Ayyad Marrakech of Morocco, with the first paper published in 2008. Even so, Hakkou managed to place ninth. Karen A. Hudson-Edwards of the University of Exeter was the author with the largest average number of citations per article with a total of 48.7. Figure 4 shows a network map illustrating the collaborative relationships of co-authorship between the different authors of MW articles. The size of the circle indicates the number of articles, whereas the thickness of the line indicates the number of collaborations between authors. The formation of different clusters can be observed through the colored representation. The group made up by Blowes, Smith, Ptacek, and Jambor stands out. Yanful leads a cluster that includes Simms, Hendry, Morris, and Song, among others. In the Benzaazoua group, we also find Bussière and Hakkou, whereas Craw, Lottermoser, and Schippers create another cluster. Next to Öhlander we can find Nason, Mäkitalo, Alakangas, and Maurice. Conesa shares the group with Jiménez-Cárceles, Robinson, Schulin, Álvarez-Rogel, and Elbaz-Poulichet. Hudson-Edwards builds a group together with Macklin, Bird, and Kossoff, among others.

Table 6. Most productive authors in MW research.

\begin{tabular}{|c|c|c|c|c|c|c|c|c|}
\hline Author & A & TC & TC/A & H Index * & $\mathrm{C}$ & Affiliation & 1st A & Last A \\
\hline Blowes, David W. & 33 & 1394 & 42.2 & 20 & Canada & University of Waterloo & 1994 & 2017 \\
\hline Yanful, Ernest Kwesi & 33 & 481 & 14.6 & 14 & Canada & Western University & 1997 & 2013 \\
\hline Benzaazoua, Mostafa & 28 & 378 & 13.5 & 11 & Canada & $\begin{array}{l}\text { Universite du Quebec en } \\
\text { Abitibi-Temiscamingue }\end{array}$ & 2004 & 2017 \\
\hline Bussière, Bruno & 28 & 404 & 14.4 & 11 & Canada & $\begin{array}{l}\text { Universite du Quebec en } \\
\text { Abitibi-Temiscamingue }\end{array}$ & 2004 & 2017 \\
\hline Craw, David & 24 & 501 & 20.9 & 14 & $\begin{array}{l}\text { New } \\
\text { Zealand }\end{array}$ & University of Otago & 1999 & 2017 \\
\hline Öhlander, Björn & 23 & 311 & 13.5 & 10 & Sweden & Lulea tekniska Universitet & 1999 & 2016 \\
\hline Conesa, Héctor Miguel & 21 & 573 & 27.3 & 11 & Spain & $\begin{array}{c}\text { Universidad Politecnica de } \\
\text { Cartagena }\end{array}$ & 2006 & 2017 \\
\hline Lottermoser, Bernd G. & 18 & 419 & 23.3 & 12 & Germany & $\begin{array}{c}\text { Rheinisch-Westfalische } \\
\text { Technische Hochschule } \\
\text { Aachen }\end{array}$ & 1999 & 2016 \\
\hline Hakkou, R. & 17 & 223 & 13.1 & 8 & Morocco & $\begin{array}{c}\text { University Cadi Ayyad } \\
\text { Marrakech }\end{array}$ & 2008 & 2017 \\
\hline $\begin{array}{l}\text { Hudson-Edwards, } \\
\text { Karen A. }\end{array}$ & 17 & 828 & 48.7 & 11 & UK & University of Exeter & 1996 & 2017 \\
\hline Schippers, Axel & 17 & 489 & 28.8 & 13 & Germany & $\begin{array}{c}\text { Bundesanstalt fur } \\
\text { Geowissenschaften und } \\
\text { Rohstoffe }\end{array}$ & 1995 & 2014 \\
\hline
\end{tabular}

* Only sample items. A: annual number of total articles; TC: annual number of citations in total articles; TC/A: number of citations by article; C: country. 


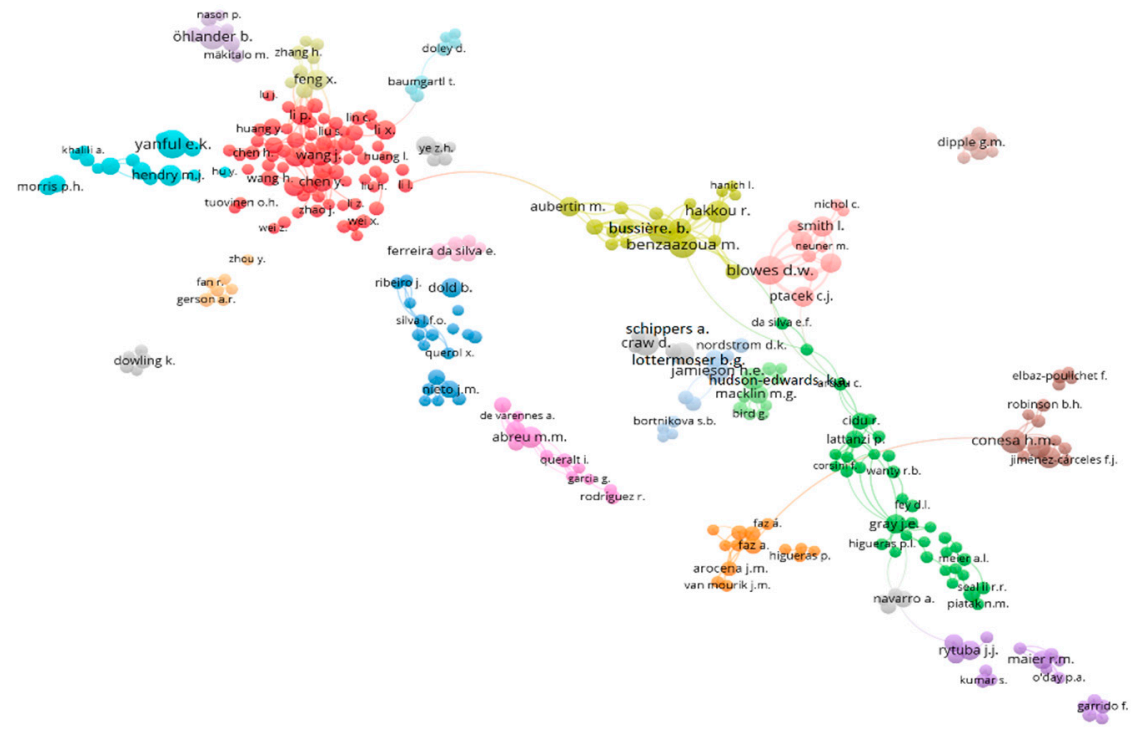

Figure 4. Cooperation based on co-authorship between authors.

We analyzed keywords to identify trends in MW research, which was necessary in order to previously remove duplicities. This pre-treatment of keywords has been undertaken with the SciMAT software. Words such as "article" and "priority journal" were excluded from this process, as they were irrelevant for our purposes. Table 7 shows the 20 most frequently used keywords in articles during the period of 1988 to 2017. This table also shows the evolution of these words through the three different 10-year sub-periods, into which the complete period may be divided. The values refer to the number of articles in which each keyword appears (A), the position the word occupies in relation to the others in terms of the number of repetitions $(R)$, and the percentage of appearances with respect to the total number of articles analyzed in the period (\%). Among the most often-used keywords were mining products (zinc, lead, copper, metals, heavy metal, iron, and arsenic), different terms relating to the processes and elements of mining (tailings, acid mine drainage, concentration, industrial waste, oxidation, and environmental monitoring), and soil contamination (soils, soil pollutants, $\mathrm{pH}$, and soil pollution).

Table 7. Most frequently used keywords in MW research.

\begin{tabular}{ccccccccc}
\hline \multirow{2}{*}{ Keywords } & \multicolumn{2}{c}{$\mathbf{1 9 8 8}-\mathbf{2 0 1 7}$} & \multicolumn{2}{c}{$\mathbf{1 9 8 8 - 1 9 9 7}$} & \multicolumn{2}{c}{$\mathbf{1 9 9 8 - 2 0 0 7}$} & \multicolumn{2}{c}{$\mathbf{2 0 0 8 - 2 0 1 7}$} \\
\cline { 2 - 8 } & $\mathbf{A}$ & $\mathbf{\%}$ & $\mathbf{R}(\mathbf{A})$ & $\mathbf{\%}$ & $\mathbf{R}(\mathbf{A})$ & $\mathbf{\%}$ & $\mathbf{R}(\mathbf{A})$ & $\mathbf{\%}$ \\
\hline Mining & 1315 & 36.8 & $1(49)$ & 20.8 & $1(435)$ & 35.2 & $1(831)$ & 39.5 \\
Tailings & 895 & 25.0 & $30(8)$ & 3.4 & $2(319)$ & 25.8 & $2(568)$ & 27.0 \\
Heavy Metal & 686 & 19.2 & $3(30)$ & 12.7 & $3(247)$ & 20.0 & $3(409)$ & 19.4 \\
Lead & 571 & 16.0 & $6(20)$ & 8.5 & $8(145)$ & 11.7 & $4(406)$ & 19.3 \\
Zinc & 561 & 15.7 & $8(19)$ & 8.1 & $6(165)$ & 13.4 & $7(377)$ & 17.9 \\
Soil Pollution & 547 & 15.3 & $8(19)$ & 8.1 & $9(137)$ & 11.1 & $5(391)$ & 18.6 \\
Soils & 537 & 15.0 & $5(22)$ & 9.3 & $10(131)$ & 10.6 & $6(384)$ & 18.2 \\
Copper & 527 & 14.7 & $4(23)$ & 9.7 & $5(172)$ & 13.9 & $9(332)$ & 15.8 \\
Acid Mine Drainage & 490 & 13.7 & $19(13)$ & 5.9 & $4(185)$ & 15.0 & $13(291)$ & 13.8 \\
Arsenic & 460 & 12.9 & $23(11)$ & 4.7 & $7(153)$ & 12.4 & $11(296)$ & 14.1 \\
Metals & 420 & 11.7 & $23(11)$ & 4.7 & $24(92)$ & 7.4 & $10(317)$ & 15.1 \\
Mine Tailings & 407 & 11.4 & $15(14)$ & 5.9 & $24(92)$ & 7.4 & $11(296)$ & 14.1 \\
pH & 385 & 10.8 & $20(12)$ & 5.1 & $20(108)$ & 8.7 & $14(265)$ & 12.6 \\
\hline
\end{tabular}


Table 7. Cont.

\begin{tabular}{ccccccccc}
\hline \multirow{2}{*}{ Keywords } & \multicolumn{2}{c}{$\mathbf{1 9 8 8 - 2 0 1 7}$} & \multicolumn{2}{c}{$\mathbf{1 9 8 8 - 1 9 9 7}$} & \multicolumn{2}{c}{$\mathbf{1 9 9 8 - 2 0 0 7}$} & \multicolumn{2}{c}{$\mathbf{2 0 0 8 - 2 0 1 7}$} \\
\cline { 2 - 8 } & $\mathbf{A}$ & $\mathbf{\%}$ & $\mathbf{R}(\mathbf{A})$ & $\mathbf{\%}$ & $\mathbf{R}(\mathbf{A})$ & $\mathbf{\%}$ & $\mathbf{R}(\mathbf{A})$ & $\mathbf{\%}$ \\
\hline Concentration (Composition) & 366 & 10.2 & 0 & 0.0 & $291(13)$ & 1.1 & $8(353)$ & 16.8 \\
Environmental Monitoring & 356 & 10.0 & $72(4)$ & 1.7 & $17(114)$ & 9.2 & $15(238)$ & 11.3 \\
Industrial Waste & 349 & 9.8 & $13(15)$ & 6.4 & $12(122)$ & 9.9 & $19(212)$ & 10.1 \\
Non-human & 347 & 9.7 & $15(14)$ & 5.9 & $13(119)$ & 9.6 & $18(214)$ & 10.2 \\
Iron & 327 & 9.1 & $30(8)$ & 3.4 & $18(109)$ & 8.8 & $20(210)$ & 10.0 \\
Oxidation & 318 & 8.9 & $15(14)$ & 5.9 & $11(128)$ & 10.4 & $27(176)$ & 8.4 \\
Soil Pollutants & 306 & 8.6 & $100(3)$ & 1.3 & $33(72)$ & 5.8 & $16(231)$ & 11.0 \\
\hline
\end{tabular}

R: ranking position; A: annual number of total articles.

As expected, the term most used during the entire study period was mining. The rest of the keywords varied their positions in accordance with the research preferences of each period. Although the words in the table were the most used, their importance oscillated over time. From 1988 to 1997, the most common keywords were mining, contamination, heavy metal, copper, soil, lead, water pollution, soil pollution, zinc, and environmental impact. During this time, the materials that were most studied were heavy metals, copper, lead, zinc, cadmium, and uranium. Attention was focused on both soil and water contamination (contamination, environmental impact, industrial wastes, waste disposal, sediment). The most frequently named countries in keywords were Canada, the United States, and Australia.

The most relevant keywords during the 1998-2007 sub-period, apart from mining, were: "tailings", "heavy metal", "acid mine drainage", "copper", "zinc", "arsenic", "lead", "soil pollution", and "soils". The principle elements that were analyzed were copper, zinc, lead, and arsenic, with the latter attracting more attention in this period compared with the previous. Acid drainage received particular attention, moving from position 19 in the previous period to fourth. Notably, the amount of attention paid to tailings in this period rose from 30th position to second place. However, the use of monitoring to study the environment experienced the greatest boost in this period, entering the list of 20 principle themes, from position number 72 during the 1988-1997 period. Conversely, studies on water contamination were no longer among the most numerous. In terms of geographic location, the regions with most studies on MW were Eurasia and Europe, and the countries were the United States, Spain, and Canada. The term "world" appears for the first time, indicating the gaining global significance of the research in this field.

The largest number of articles was published from 2008 to 2017; therefore, the greatest number of keyword repetitions were concentrated in this period. This conditioned the current framework of keywords. The principle keywords during this time were "mining", "tailings", "heavy metal", "lead", "soil pollution", "soils", "zinc", "concentration", "copper", and "metals". The two things of note during this period were the consolidation of a preference for studies of the ground rather than water, and the emergence of the term "concentration" in MW articles. From no presence at all in the previous periods, "concentration" became the eighth most common keyword. Studies of abandoned mines began to appear more frequently. Geographical reference takes 52nd place among keywords, with the United States closely followed by Spain and China.

Figure 5 shows a network map of the co-occurrence of the main keywords. The size of the circle represents the number of repetitions, and the color shows the different clusters in which the words are grouped according to the number of ties between the different words. Three main groups were found. The first (green) is titled "Contamination and public health". In this cluster, elements such as potassium, arsenic, aluminum, antimony, cobalt, copper, zinc, and lead are analyzed. The cluster includes terminology related to health, both human and animal, such as "health risk", "health hazard", "public health", "drinking water", "animals", "fish", "human", "pollution exposure", etc. The principle methodology terms gathered here are: "multivariate analysis", "principal component analysis", and "risk assessment". The main countries in this line were the 
United States, the United Kingdom, Spain, and Portugal. The second group (red) is called "Waste management", and includes the terms: "metal recovery", "heavy metal removal", "neutralization", "waste management", and "waste treatment". This group presents a perspective from the fields of Hydrology and Hydrogeology. The most significant methodology terms were "analytic method", "analytical geochemistry", "chemical analysis", "computer simulation", and "experimental study". Brazil, Canada, Germany, South Africa, and Sweden appear in this group. The last cluster (blue), called "Ecological restoration", includes China, Australia, and India as the foremost countries with an environmental orientation. Terminology relating to the ground appears in this cluster, including: soil composition, microbiological activity, and revegetation (ecology, plant restoration, revegetation, ecosystem restoration, soils, soil microbiology, soil conservation, soil analysis, soil remediation, microbiology, microbial activity, etc.). The outstanding methodology terms are: "microbial analysis", "controlled study", and "comparative study".

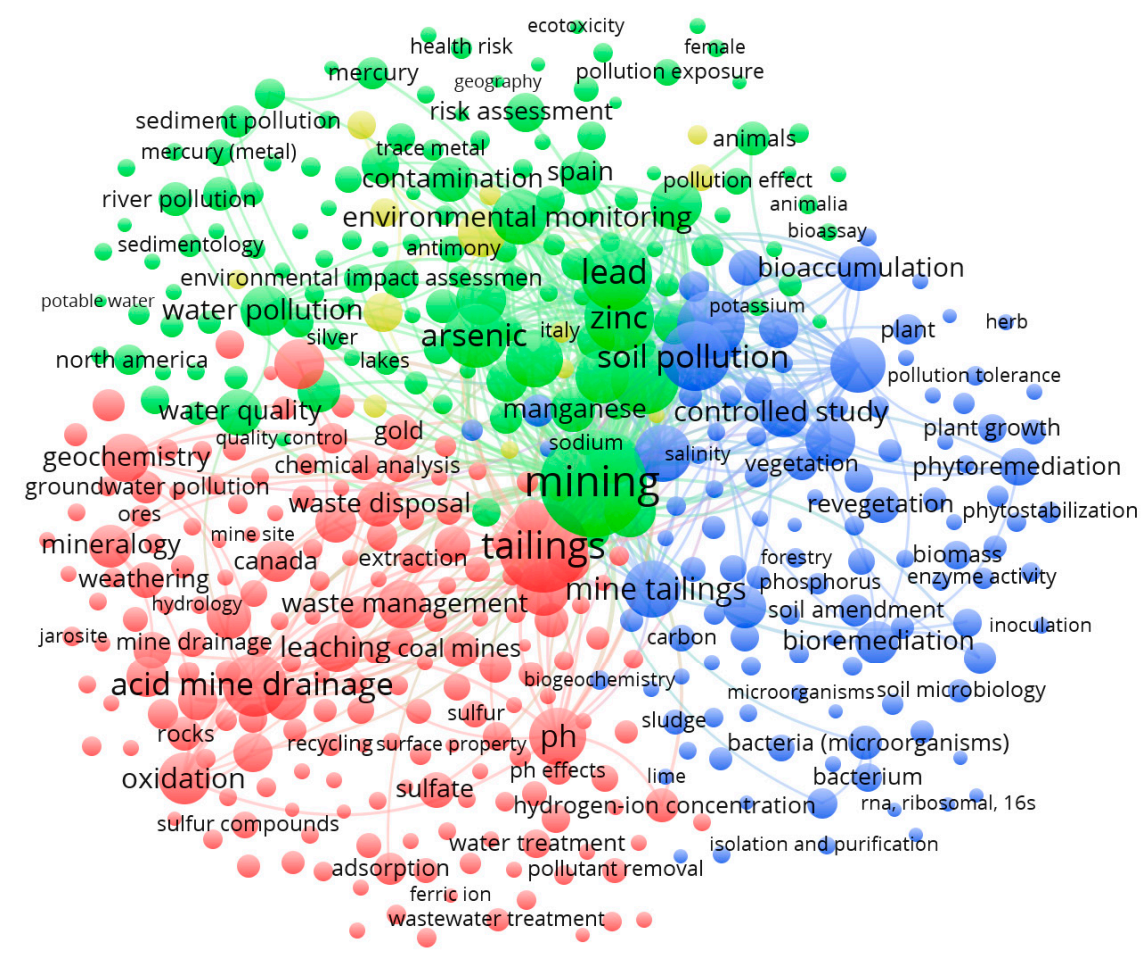

Figure 5. Main keywords' co-occurrence network in MW research.

\subsection{Management of Mining Waste}

In this section, we present the main analysis results of the evolution of worldwide research into the management of mining waste (MMW) during the period of 1988 to 2017. Table 8 shows the evolution of the principle indicators of research in this field. The number of articles on MMW (A) increased from one in 1988 to 100 in 2017. To contextualize the increase in articles in this line of research, Figure 6 displays the growing trend in the number of research articles on mining, mine waste (MW), and the management of mine waste (MMW). To facilitate the comparison and homogenize variables, logarithms were applied to them, and the annual average accumulated growth rate was calculated. As a result, although articles on mining increased by $7.54 \%$ on average per year, those on MW increased by $10.87 \%$, and those on MMW increased by $17.52 \%$. Figure 6 shows a great variability regarding the growth trends of the published articles on these three fields of research until the last decade of the 20th century. As far as the growth trend of mining articles (in green) is concerned, it did not start to be positive until 1998. Therefore, in the field of mining research, MW and particularly MMW have become increasingly important. 
To analyze the contribution of research into MMW to MW, Table 8 shows a variable indicating the percentage of MW articles corresponding to research on MMW (AMW). Research into MMW gained importance within the field of MW in terms of the number of articles. In 1988, articles on management represented only $7.1 \%$ of the total; in 2017 , they represented $38.7 \%$.

Table 8. Major characteristics of the articles published on MMW.

\begin{tabular}{cccccccccc}
\hline Year & A & AU & NR & J & C & TC & CTC/CA & AMW & TCMW \\
\hline 1988 & 1 & 1 & ND & 1 & 1 & 0 & 0.0 & 7.1 & 0.0 \\
1989 & 2 & 5 & 7 & 2 & 2 & 0 & 0.0 & 13.3 & 0.0 \\
1990 & 6 & 9 & 42 & 5 & 3 & 0 & 0.0 & 33.3 & 0.0 \\
1991 & 3 & 11 & 82 & 3 & 2 & 1 & 0.1 & 14.3 & 5.6 \\
1992 & 1 & 5 & ND & 1 & 3 & 1 & 0.2 & 12.5 & 4.2 \\
1993 & 7 & 13 & 106 & 7 & 4 & 2 & 0.2 & 26.9 & 5.7 \\
1994 & 3 & 8 & 58 & 3 & 2 & 2 & 0.3 & 13.6 & 3.8 \\
1995 & 2 & 6 & 44 & 2 & 2 & 12 & 0.7 & 6.3 & 15.0 \\
1996 & 13 & 27 & 426 & 11 & 6 & 13 & 0.8 & 34.2 & 10.7 \\
1997 & 6 & 13 & 53 & 6 & 3 & 25 & 1.3 & 14.3 & 15.1 \\
1998 & 20 & 58 & 416 & 18 & 14 & 26 & 1.3 & 25.3 & 12.7 \\
1999 & 27 & 86 & 712 & 21 & 9 & 64 & 1.6 & 27.6 & 19.9 \\
2000 & 34 & 100 & 877 & 25 & 12 & 76 & 1.8 & 31.5 & 20.5 \\
2001 & 30 & 95 & 709 & 24 & 13 & 102 & 2.1 & 28.0 & 22.0 \\
2002 & 30 & 101 & 744 & 25 & 18 & 168 & 2.7 & 23.8 & 25.3 \\
2003 & 36 & 136 & 805 & 28 & 17 & 258 & 3.4 & 27.9 & 26.7 \\
2004 & 53 & 152 & 1707 & 39 & 24 & 264 & 3.7 & 38.7 & 25.9 \\
2005 & 42 & 142 & 1434 & 31 & 21 & 349 & 4.3 & 26.4 & 23.8 \\
2006 & 39 & 129 & 1314 & 23 & 21 & 472 & 5.2 & 30.7 & 25.5 \\
2007 & 41 & 137 & 1144 & 32 & 24 & 613 & 6.2 & 24.8 & 27.9 \\
2008 & 41 & 135 & 1304 & 31 & 20 & 810 & 7.5 & 25.5 & 30.2 \\
2009 & 57 & 194 & 1864 & 42 & 26 & 914 & 8.4 & 33.1 & 28.9 \\
2010 & 54 & 205 & 2204 & 33 & 30 & 1062 & 9.6 & 32.1 & 30.0 \\
2011 & 59 & 194 & 2305 & 34 & 25 & 1304 & 10.8 & 28.8 & 30.7 \\
2012 & 61 & 224 & 2219 & 36 & 24 & 1393 & 11.9 & 34.5 & 31.2 \\
2013 & 73 & 234 & 3091 & 51 & 28 & 1589 & 12.8 & 31.3 & 30.7 \\
2014 & 72 & 320 & 2995 & 48 & 33 & 1995 & 14.2 & 31.3 & 32.8 \\
2015 & 72 & 280 & 2784 & 52 & 31 & 2061 & 15.3 & 31.9 & 32.4 \\
2016 & 100 & 418 & 4562 & 60 & 37 & 2457 & 16.3 & 39.2 & 33.9 \\
2017 & 108 & 504 & 4791 & 71 & 36 & 2677 & 17.1 & 38.7 & 36.1 \\
\hline
\end{tabular}

A: annual number of articles; AU: annual number of authors; NR: total number of references for all articles; J: annual number of journals; C: annual number of countries; TC: annual number of citations for all articles; CTC/CA: annual total citations per cumulative article; AMW: percentage of annual contribution of MMW to MW (annual number of articles of MMW/annual number of articles of MW); TCMW: percentage of annual contribution of MMW citation to MW citation (annual number of citations of MMW/annual number of citations of MW). 


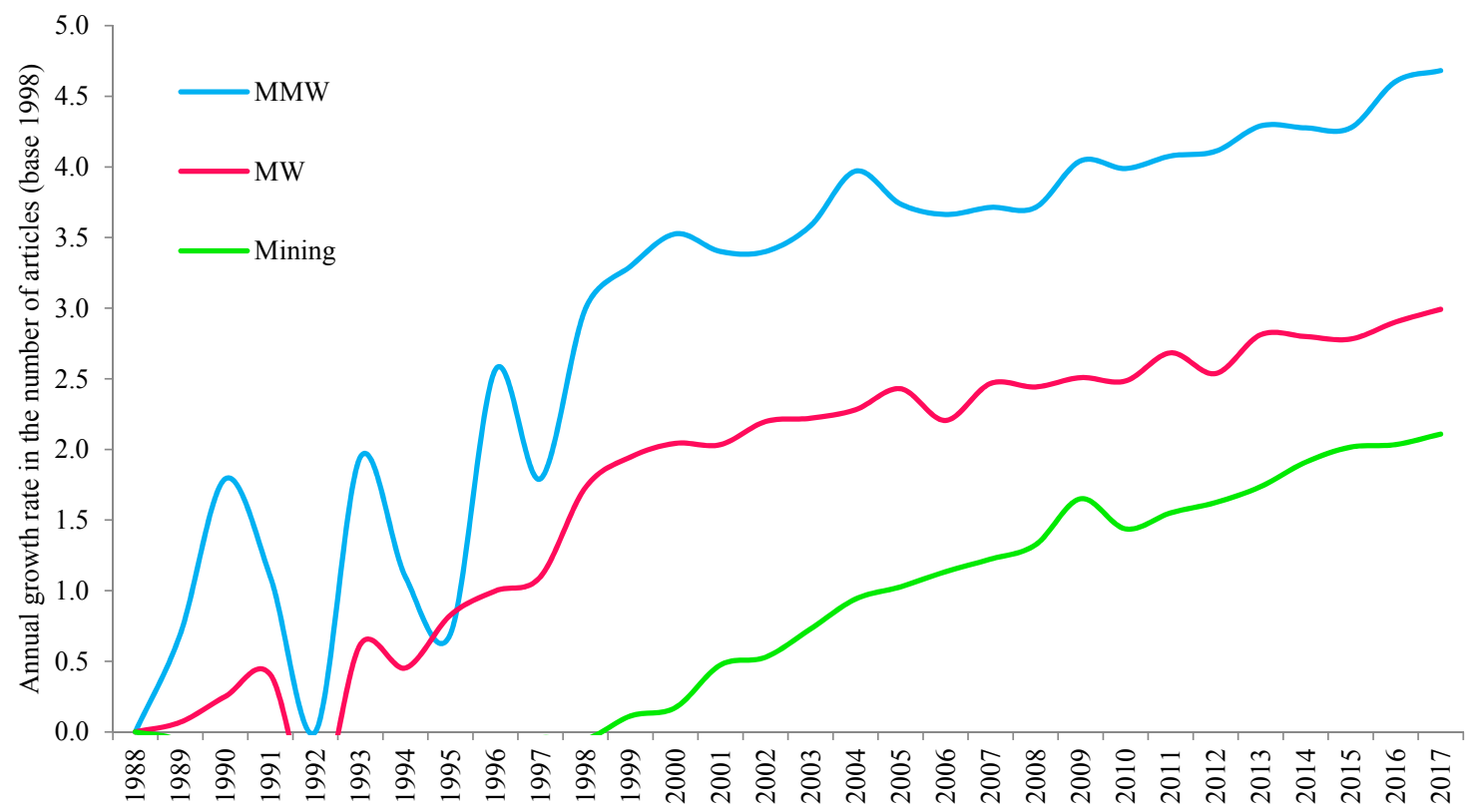

Figure 6. Comparative trends in the number of articles of mining, MW, and the management of mining waste (MMW) research.

Table 9 shows the main variables of the most productive journals on MMW. If we compare this group of journals to Table 2, we find a group of journals that published both on MW and MMW, their position in the ranking of most productive journals changed. In both cases, Applied Geochemistry was the most productive journal. The articles on MMW make up $29 \%$ of the total number of articles on MW. The Journal of Hazardous Materials and Chemosphere occupied the first and fourth positions, respectively, and are the only publications that improved their positions with respect to research on MW. For the former, articles on MMW accounted for $66.2 \%$ of the total number of articles on MW, whereas the latter accounted for $55.2 \%$ of the total articles. The Journal of Environmental Management, Environmental Science and Pollution Research, and Ecological Engineering were placed seventh, eighth, and $10^{\text {th }}$, respectively. These three publications did not appear in the most productive group on MW. Similarly, Environmental Geology, Environmental Science and Technology, and Environmental Pollution were not among the most productive journals on MMW research. 
Table 9. Top 10 most productive journals for MMW research.

\begin{tabular}{|c|c|c|c|c|c|c|c|c|c|c|}
\hline \multirow{2}{*}{ Journal } & \multirow{2}{*}{$\mathbf{A}$} & \multirow{2}{*}{ SJR } & \multirow{2}{*}{ H Index } & \multirow{2}{*}{$\mathrm{C}$} & \multirow{2}{*}{ TC } & \multirow{2}{*}{ TC/A } & \multirow{2}{*}{ 1st A } & \multicolumn{3}{|c|}{$\mathrm{R}(\mathrm{A})$} \\
\hline & & & & & & & & 1988-1997 & 1998-2007 & 2008-2017 \\
\hline Applied Geochemistry & 45 & $1.019(\mathrm{Q} 1)$ & 22 & UK & 1312 & 29.2 & 1991 & $5(1)$ & $2(13)$ & $3(31)$ \\
\hline Journal of Hazardous Materials & 45 & $1.727(\mathrm{Q} 1)$ & 20 & Netherlands & 1205 & 26.8 & 2002 & 0 & $6(8)$ & $1(37)$ \\
\hline Science of the Total Environment & 43 & $1.621(\mathrm{Q} 1)$ & 20 & Netherlands & 1887 & 43.9 & 1999 & 0 & $1(16)$ & $5(27)$ \\
\hline Chemosphere & 37 & $1.417(\mathrm{Q} 1)$ & 16 & UK & 1293 & 34.9 & 2003 & 0 & $11(7)$ & $4(30)$ \\
\hline Environmental Earth Sciences & 33 & $0.574(\mathrm{Q} 2)$ & 10 & Germany & 268 & 8.1 & 2009 & 0 & 0 & $2(33)$ \\
\hline Journal of Geochemical Exploration & 29 & $1.047(\mathrm{Q} 1)$ & 15 & Netherlands & 631 & 21.8 & 1998 & 0 & $11(7)$ & $7(22)$ \\
\hline Journal of Environmental Management & 26 & $1.141(\mathrm{Q} 1)$ & 11 & USA & 346 & 13.3 & 2005 & 0 & $35(2)$ & $6(24)$ \\
\hline Environmental Science and Pollution Research & 22 & $0.813(\mathrm{Q} 2)$ & 8 & Germany & 150 & 6.8 & 2010 & 0 & 0 & $7(22)$ \\
\hline Water Air and Soil Pollution & 22 & $0.578(\mathrm{Q} 2)$ & 13 & Netherlands & 479 & 21.8 & 2002 & 0 & $6(8)$ & $10(14)$ \\
\hline Ecological Engineering & 20 & $1.053(\mathrm{Q} 1)$ & 9 & Netherlands & 219 & 11.0 & 2002 & 0 & $24(3)$ & $9(17)$ \\
\hline
\end{tabular}

A: annual number of total articles; SJR: Scopus Journal Ranking; C: country; TC: annual number of citations for all articles; TC/A: number of citations by article; 1st A: first article of MMW research by journal; R: ranking position. 
The group of the 10 most productive journals on MMW included $29 \%$ of the total, indicating a wide distribution of publications on this theme. All of the publications included were among the first or second quartile in SJR ranking. The journal with the most citations was Science of the Total Environment with 1887; it also had the greatest average number of citations per article, with 43.9. The Journal of Hazardous Materials was the publication with the greatest SJR index (1.727).

Table 10 shows the list of the 10 most productive countries publishing articles on MMW. Once again, the United States was the country with the most articles, followed by Canada, Spain, China, and Australia. This means that the five most productive countries on MMW coincided with those on MW. In terms of the number of citations, the United States was the most important, followed by Canada, Spain, and the United Kingdom. As with research on MW, taking into account the average number of citations per article, the United Kingdom was placed first, with 27.5 citations per article, followed by Portugal with 22, Sweden with 21.5, and the United States with 21. The table also includes the percentage of articles on MMW compared with the number of articles on MW (AMW) of each of the nine most productive countries in both research fields. The country with the largest percentage of articles on management of the total works on MW was India with $40 \%$, followed by Portugal with $36.5 \%$, the United States with $33.4 \%$, and Spain with $32.4 \%$.

Table 10. Most productive countries in MMW research.

\begin{tabular}{cccccccc}
\hline Country & A & TC & TC/A & AMW & \multicolumn{3}{c}{ R (A) } \\
\cline { 6 - 7 } & & & & & $\mathbf{1 9 8 8 - 1 9 9 7}$ & $\mathbf{1 9 9 8 - 2 0 0 7}$ & $\mathbf{2 0 0 8 - 2 0 1 7}$ \\
\hline United States & 205 & 4310 & 21.0 & 33.4 & $1(15)$ & $1(82)$ & $1(108)$ \\
Canada & 128 & 2333 & 18.2 & 25.7 & $3(3)$ & $2(51)$ & $3(74)$ \\
Spain & 110 & 2229 & 20.3 & 32.4 & 0 & $6(22)$ & $2(88)$ \\
China & 90 & 1589 & 17.7 & 32.1 & 0 & $7(19)$ & $4(71)$ \\
Australia & 79 & 1063 & 13.5 & 26.2 & $6(1)$ & $7(19)$ & $5(59)$ \\
United Kingdom & 75 & 2065 & 27.5 & 31.1 & $2(7)$ & $4(30)$ & $7(38)$ \\
India & 68 & 711 & 10.5 & 40.0 & 0 & $5(24)$ & $6(44)$ \\
Germany & 56 & 850 & 15.2 & 29.9 & $3(3)$ & $3(33)$ & $13(20)$ \\
Portugal & 38 & 837 & 22.0 & 36.5 & 0 & $13(7)$ & $8(31)$ \\
South Africa & 32 & 323 & 10.1 & ND & $6(1)$ & $11(8)$ & $11(23)$ \\
Sweden & 32 & 688 & 21.5 & ND & $5(2)$ & $9(15)$ & $17(15)$ \\
\hline
\end{tabular}

A: annual number of total articles; TC: annual number of citations for all articles; TC/A: number of citations by article; AMW: percentage of contribution of MMW to MW (number of articles of MMW/number of articles of MW); R: ranking position.

Table 11 shows the main characteristics of the institutions with the greatest number of articles on MMW. Sweden's Lulea Tekniska Universitet had the most publications. This institution does not stand out for its production of articles on MW; however, it is a reference for MMW. Spain's Universidad Politécnica de Cartagena had the same number of publications, and was included among the group of most important producers of MW articles. However, its first-place ranking in MMW research means this is one of its most important areas of research. Other institutions that gained ground with respect to Table 5 are the United States Geological Survey, which was ranked third, and Spain's National Research Council in fifth place. Other institutions that did not appear among the most productive in MW, but did for MMW, were the Universidade de Lisboa (Portugal), the United States Environmental Protection Agency, the Universidad Politécnica de Cataluña (Spain), and the Universidade de Aveiro (Portugal). The United States Geological Survey is the institution with the greatest number of citations, followed by the National Research Council of Spain, the United States Environmental Protection Agency, and the Universidad Politécnica de Cartagena (Spain). In the ranking of average citations per article, these institutions remained in the same order. Those with the largest percentage of articles produced in collaboration were: the Universidade de Lisboa and the Université du Quebec in Abitibi-Temiscamingue with 50\% of the total. These were followed by Spain's National Research Council with $43.8 \%$, and Sweden's Lulea Tekniska Universitet with 38.9\%. 
Table 11. Most productive institutions in MMW research.

\begin{tabular}{|c|c|c|c|c|c|c|c|c|}
\hline \multirow{2}{*}{ Institution } & \multirow{2}{*}{$\mathrm{C}$} & \multirow{2}{*}{ A } & \multirow{2}{*}{ TC } & \multirow{2}{*}{ TC/A } & \multirow{2}{*}{ H Index * } & \multirow{2}{*}{ IC (\%) } & \multicolumn{2}{|c|}{ TC/A } \\
\hline & & & & & & & IC & NIC \\
\hline Lulea tekniska Universitet & Sweden & 18 & 248 & 13.8 & 9 & 38.89 & 9.1 & 16.7 \\
\hline Universidad Politecnica de Cartagena & Spain & 18 & 422 & 23.4 & 9 & 33.33 & 49.7 & 10.3 \\
\hline United States Geological Survey & USA & 17 & 658 & 38.7 & 10 & 11.76 & 8.0 & 42.8 \\
\hline Consejo Superior de Investigaciones Científicas & Spain & 16 & 538 & 33.6 & 10 & 43.75 & 20.7 & 43.7 \\
\hline Chinese Academy of Sciences & China & 16 & 339 & 21.2 & 10 & 25.00 & 27.3 & 19.2 \\
\hline The University of British Columbia & Canada & 15 & 142 & 9.5 & 6 & 26.67 & 8.3 & 9.9 \\
\hline Universidade de Lisboa & Portugal & 14 & 154 & 11.0 & 6 & 50.00 & 3.3 & 18.7 \\
\hline United States Environmental Protection Agency & USA & 13 & 433 & 33.3 & 8 & 15.38 & 5.5 & 38.4 \\
\hline University of Queensland & Australia & 13 & 73 & 5.6 & 6 & 15.38 & 0.5 & 6.5 \\
\hline Universite du Quebec en Abitibi-Temiscamingue & Canada & 12 & 61 & 5.1 & 5 & 50.00 & 8.2 & 2.0 \\
\hline Universitat Politecnica de Catalunya & Spain & 12 & 201 & 16.8 & 8 & 33.33 & 12.0 & 19.1 \\
\hline Universidade de Aveiro & Portugal & 12 & 128 & 10.7 & 7 & 25.00 & 6.3 & 12.1 \\
\hline
\end{tabular}

* Only sample items. C: country; A: annual number of total articles; TC: annual number of citations in total articles;

TC/A: number of citations by article; IC: international collaborations; NIC: no international collaborations.

\subsection{Sustainable Management of Mining Waste}

\subsubsection{Quantitative Analysis}

This section shows the main results obtained from the quantitative analysis of the article sample on sustainable management of mine waste (SMMW). The definitive sample was made up of 59 articles. Due to this small number of results, documents can be shown in an abbreviated manner.

The first found article dates from 1992. From then on, the number of articles published on this topic is highly irregular. Until 1998, there was no continuity in the publication of articles. In 2017, a total amount of 10 articles can be found. The main journals regarding the publication number on this field are Ecological Engineering, Minerals, Environmental Earth Sciences, Environmental Science and Pollution Research, the Journal of Environmental Management, the Journal of Geochemical Exploration, and the Journal of Hazardous Materials. When the groups of the main journals, according to the number of articles on the three main studied topics, are compared (MW, MMW, SMMW), some different publication trends are observed. Applied Geochemistry is the most productive journal in the two main topics. It is the leader publication on waste management studies. However, this is not the case within the sustainability field. It also occurs with Science of the Total Environment, Chemosphere, and Water, Air, and Soil Pollution. Differently, we could find three journals ranking at the first positions within the three research fields. They are the Journal of Hazardous Materials, Environmental Earth Sciences, and the Journal of Geochemical Exploration. These journals embrace the whole spectrum of mine waste management, including sustainability. The Journal of Environmental Management, Environmental Science and Pollution Research, and Ecological Engineering also stand out in the general management and sustainable management areas. The latter is also the most productive one on SMMW. Finally, a journal that was not outstanding in the two first topics occupies the second position on SMMW. We refer to the journal Minerals, which has placed itself as a leading specialist and a reference journal on the sustainable management of mine waste.

Authors with the highest number of publications were Banning, N.C.; Fan, R.; Gerson, A.R.; Huang, L.; Kawashima, N.; Li, J.; Li, X.; Lottermoser, B.G.; Qian, G.; Schumann, R.C.; Short, M.D.; and Smart, R.S.C. As far as authors are concerned, only six of the 10 most important ones on WM were to be found publishing on MMW. Öhlander and Conesa share the first position; followed by Blowes, Benzaazoua, Hudson-Edwards, and Lottermoser. The last author is also one of the most prolific ones on SMMW. This can suggest the great diversity of fields within the study of mine waste. The most relevant institutions came from Australia: the University of Queensland, the University of Western Australia, and the University of South Australia. All of the institutions in Table 5 are also active in Table 11, except for the Western University, the University of Saskatchewan, and the University of Waterloo. It can be stated that the three Australian institutions are the only institutions that stand out in the three analyzed fields of research. The country with the highest number of articles is Australia, 
followed by Canada, the United States, China, India, Spain, and the United Kingdom. These countries configure the most relevant group regarding the publications on the three studied topics.

The Environmental Science category includes a greater number of articles, resulting in 59.3\% out of the total, followed by Earth and Planetary Sciences with 38.9\%, Agricultural and Biological Sciences with $15.3 \%$, Engineering with $15.3 \%$, and Materials Science with $6.8 \%$. In contrast, the Economics, Econometrics and Finance, and Social Sciences categories have only two documents, and the multidisciplinary category only has one. This implies an absolute predominance of Environmental Sciences and Engineering regarding these studies. This result can be also obtained within the other two analyzed topics (MW and MMW).

\subsubsection{Qualitative Analysis}

In the qualitative analysis, works on SMMW were divided up according to the two main aspects on which the articles focus: scope of sustainability and focus of action. Table 12 comprises the 59-article sample grouped by these two features.

Table 12. Articles published on the sustainable management of mine waste (SMMW).

\begin{tabular}{|c|c|c|}
\hline Scope of Sustainability & Focus of Action & Article \\
\hline \multirow{17}{*}{ Environmental } & $\begin{array}{l}\text { Stabilization and waste } \\
\text { treatment }\end{array}$ & $\begin{array}{l}\text { Li, X., Huang, L. [61]; Li, X. et al. [62]; Qian et al. [63]; } \\
\text { Ogbughalu et al. [64] }\end{array}$ \\
\hline & Evaluation of environmental & Ellis, D.V. [65]; Miler, M.; Gosar, M. [66]; Méndez-Ramírez, M.; \\
\hline & & Bansch, C.; Topp, W. [68]; Gatzweiler et al. [69]; Ghose, M.K. [70]; \\
\hline & & Elshorbagy et al. [71]; Bowen et al. [72]; Van Deventer, P.W.; \\
\hline & & Bloem, A.A.; Hattingh, J.M. [73]; Maddocks, G.; Lin, C.; \\
\hline & & McConchie, D. [74]; Lottermoser, B.G.; Glass, H.J.; Page, C.N. [75]; \\
\hline & & Wu et al. [76]; Pepper et al. [77]; Melgar-Ramírez et al. [78]; \\
\hline & Remediation and recovery of & Valente et al. [79]; Courtney, R. [80]; Bigot et al. [81]; Adams, A.; \\
\hline & soils and landscape & Raman, A.; Hodgkins, D. [82]; Sjöberg et al. [83]; Naeth, M.A.; \\
\hline & & Wilkinson, S.R. [84]; Banning et al. [85]; Johansson et al. [86]; \\
\hline & & Li, J.J.; Yan, J.X.; Li, H.J. [87]; Anawar, H.M. [88]; Santini, T.C.; \\
\hline & & Banning, N.C. [89]; Nirola et al. [90]; Párraga-Aguado et al. [91]; \\
\hline & & Nancucheo et al. [92]; Plaza et al. [93]; Sözen et al. [94]; \\
\hline & & Mwandira, W.; Nakashima, K.; Kawasaki, S. [95] \\
\hline & $\begin{array}{l}\text { Reuse and recycling of } \\
\text { materials }\end{array}$ & Dold, B. [2]; Bartke, K. [96] \\
\hline & $\begin{array}{l}\text { Treatment and remediation of } \\
\text { contaminated water }\end{array}$ & $\begin{array}{l}\text { Kalin, M. [97]; Azam, S. [98]; Younger, P.L. [99]; } \\
\text { Macklin et al. [100] }\end{array}$ \\
\hline & Cooperation in the & Meech et al. [101] \\
\hline \multirow{9}{*}{ Environmental Economic } & Recycling of materials and & \\
\hline & rehabilitation of landscape & Careddu et al. [102] \\
\hline & Remediation and recovery of & Shukla, M.K.; Lal, R. [103]; Wajima, T.; Ikegami, Y. [104]; \\
\hline & soils and landscape & Hwang, T.; Neculita, C.M.; Han, J.-I. [105] \\
\hline & & Emery et al. [106]; Venkatarama Reddy, B.V. [107]; Gabzdyl, W.; \\
\hline & Reuse and recycling of & Hanak, B. [108]; Arrigo et al. [109]; Haibin, L.; Zhenling, L. [110]; \\
\hline & materials & Lottermoser, B.G. [111]; Cadierno et al. [112]; Kundu et al. [113]; \\
\hline & & Yang et al. [114]; Rana, A.; Kalla, P.; Csetenyi, L.J. [115]; \\
\hline & & Taha et al. [116]; Gorakhki, M.H.; Bareither, C.A. [117] \\
\hline
\end{tabular}

The Sustainability concept includes three fields: the economic, the environmental, and the social one [48]. According to this, the sustainable development of any activity should assure an economical use, the integrity of ecological systems, and a contribution to social welfare for current and future generations [13]. Mining activities, and especially its waste management, raise conflicts between these three fields. Waste management has an economic impact. Wastes of the mining activities are one of the main polluting agents for soil, water, and air. As far as the social aspect is concerned, mining raises interest conflicts between the main stakeholders. The welfare of the population living within the mining influence areas depends to a large extent on the appropriate management of mine waste. We can mention health hazard as an example. As the table shows, all of the analyzed articles speak of aspects relevant to the environment. The main concerns regarding sustainable waste management focus on environmental impacts. They handle pollution prevention or decontamination treatments. 
Only $28.8 \%$ of the articles include an economic perspective of waste management. No article of our selected sample was found where the impact of mine waste management on human welfare is analyzed, which is further beyond the economic and environmental impacts.

As far as the focus of action is concerned, the articles have been grouped regarding the two main sets of activities detected during the review. Sustainable waste management concentrates on two activities: material reuse and waste depollution. On the one hand, a set of articles is devoted to the incorporation of waste materials in the production process. This can be achieved through recycling, reuse, and recuperation, among other processes. On the other hand, a further set of articles focus on the treatment processes of waste and cleanup, such as bioremediation and phytoremediation. In works with an exclusive focus on environmental sustainability, 95.2\% of the articles concentrate on different depollution aspects, while $66.7 \%$ of the articles treat the remediation of soils polluted by wastes. The impacts on ecosystems and biodiversity, the stabilization of polluting agents, and the remediation of polluted water are considered by $9.5 \%$ of the publications. Material reuse can only be found in $4 \%$ of this article group.

Regarding the works focusing on economic and environmental sustainability, the reuse of waste materials stands out within $70.6 \%$ of the total publications, while only $17.6 \%$ of the articles analyzed profitable processes for the recuperation of polluted soils. One work is jointly devoted to material reutilization and depollution. A further study aims at the study of interinstitutional cooperation for the development of waste management projects that contribute to improve profitability and reduce environmental impacts.

\section{Conclusions}

This study analyzed the dynamics of global research into mining waste analysis and its sustainable management from 1988 to 2017. A systematic and bibliometric analysis was completed on a sample of 3577 articles. The results indicated a rapid increase in the number of published articles each year, growing from 14 in 1988 to 279 in 2017. This increase has occurred particularly since 2008, with 63\% of the overall total. This increase in mining waste articles and journals, authors, institutions, and countries indicated that this line of research is receiving growing worldwide attention. This is due to several factors, including concerns over environmental threats, a greater social awareness of environmental issues, and new and more restrictive regulations in developed countries. We demonstrated that mining waste and mining waste management are two fields of research with a marked differential growth rate within the field of mining research worldwide.

Applied Geochemistry, Science of the Total Environment, and the Journal of Geochemical Exploration were the journals with the largest number of articles published on mining waste. Along with the first two, the Journal of Hazardous Materials was one of the journals that published the most articles on mining waste. The United States was the country with the largest number of articles published on mining waste management, followed by Canada, Spain, Australia, and China. These are also the most prolific countries in terms of articles on managing mining waste. If you consider the average number of citations per article on mining waste, the order changes to: UK, the United States, Spain, Portugal, and Canada. Considering the population of each country, Canada was placed first. In the list of the 10 most published authors on mining waste, the top four were Canadian: Blowes, Yanful, Benzaazoua, and Bussière. The University of British Columbia, the Chinese Academy of Sciences, and the University of Queensland were the three institutions with the largest number of published papers on mining waste, whereas Sweden's Lulea Tekniska Universitet, Spain's Universidad Politécnica de Cartagena, and the United States Geological Survey were those with most articles on mining waste management.

The keywords analysis that was used in the articles studied showed that various mining products were among the most frequently used words, including: zinc, lead, copper, metals, heavy metals, iron, and arsenic. The most common terms related to processes and mining elements were: "tailings", "acid mine drainage", "concentration", "industrial waste", "oxidation", 
and "environmental monitoring". The most common terms related to soil contamination were: "soils", "soil pollutants", "pH", and "soil pollution". The network mapping of co-occurrence of keywords revealed three different clusters focused on contamination and public health, waste management, and environmental restoration.

Regarding the sustainable management of mining waste, it has been proven that this is a recent field of study. Only 59 articles were found in the sample. Although studies on sustainable mining waste management are of secondary importance, it is a field of research that shows great potential given the increasing social awareness about the environmental repercussions of mining and the increasing demands for sustainable production methods. Our analysis shows a twofold action in order to achieve the sustainable management of mining waste. On the one side, efforts to depollute mining waste are in progress. This action embraces air, water, and soil. Nevertheless, the last one has attracted the most attention to date. On the other side, the recycling of mining wastes is being developed. It enables reductions in energy consumption, the emission of greenhouse gases, and waste generation. Moreover, it also results in cost reduction and higher profitability.

Currently, the treatment of mining waste focuses on remediation, reuse, and evaluating the mined area for alternative use. Lines of research are oriented toward the application of biotechnology, the use of microbes, and bioremediation with algae, and phytoremediation. To resolve water contamination issues, the use of nutrient-enriched sediments has been proposed to reduce metal acidity and increase $\mathrm{pH}$, in addition to applying engineering systems for storage following ecological principles. Concerning the reuse of residues, it is proposed to use the link between mining and construction to convert waste into building materials. Another area of research involves investigating the use of slag and gases to generate electricity.

A relevant issue that has arisen during this research work refers to the contribution of mine waste management to sustainability. In the studies on mining waste, the term sustainability is commonly associated with environmental protection, since most works focus on it. Fewer articles have analyzed mine waste management from an economic point of view. No articles have been found where waste management contributes to social welfare, apart from those comments on health hazards. We can therefore state that there is a relevant gap in this research field. The approach to sustainability analysis should be based on multidisciplinary frameworks where technical and socio-economic methods are taken into account. This can provide relevant information for all of the involved stakeholders in the decision-making processes regarding the management of material and natural resources.

Author Contributions: The four authors have equally contributed to this paper. All authors have revised and approved the final manuscript.

Acknowledgments: This work has been partially supported by the Spanish Ministry of Economy and Competitiveness and the European Regional Development Fund by means of the research projects ECO2017-82347-P and HAR2014-56428-C3-2, and by the Research Plan of the University of Almería through a Predoctoral Contract to Juan F. Velasco Muñoz. This paper was developed during the research stay by José A. Aznar-Sánchez at the Humboldt-Universität zu Berlin.

Conflicts of Interest: The authors declare no conflict of interest.

\section{References}

1. Reichl, C.; Schatz, M.; Zsak, G. World-Mining-Data. In Minerals Production; International Organizing Committee for the World Mining Congresses: Vienna, Austria, 2016; Volume 31.

2. Dold, B. Sustainability in metal mining: From exploration, over processing to mine waste management. Rev. Environ. Sci. Bio/Technol. 2008, 7, 275-285. [CrossRef]

3. Gómez Ros, J.M.; García, G.; Peñas, J.M. Assessment of restauration success of former metal mining areas after 30 years in a highly polluted Mediterranean mining area: Cartagena-La Union. Ecol. Eng. 2013, 57, 393-402. [CrossRef]

4. Bakken, G.M. Montana, Anaconda, and the Price of Pollution. Historian 2007, 69, 36-48. Available online: http:/ / www.jstor.org/stable/24453910 (accessed on 14 April 2018). [CrossRef] 
5. Durucan, S.; Korre, A.; Muñoz-Melendez, G. Mining life cycle modelling: A cradle-to-gate approach to environmental management in the minerals industry. J. Clean. Prod. 2006, 14, 1057-1070. [CrossRef]

6. Alloway, B.J. Heavy Metals in Soils; Blackie: Glasgow, UK, 1995; ISBN 0751401986.

7. Pérez Cebada, J.D. Mining corporations and air pollution science before the Age of Ecology. Ecol. Econ. 2016, 123, 77-83. [CrossRef]

8. Pasariello, B.; Giuliano, V.; Quaresima, S.; Barbaro, M.; Caroli, S.; Forte, G.; Carelli, G.; Iavicoli, I. Evaluation of the environmental contamination at abandoned mining site. Microchem. J. 2002, 73, 245-250. [CrossRef]

9. Hudson-Edwards, K.A.; Dold, B. Mine Waste Characterization, Management and Remediation. Minerals 2015, 5, 82-85. [CrossRef]

10. Fetter, C.W. Contaminant Hydrogeology; Prentice Hall: Upper Saddle River, NJ, USA, 1999; ISBN 13 978-1577665830.

11. Iribar, V.; Izco, F.; Tames, P.; Antigüedad, I.; da Silva, A. Water contamination and remedial measures at the Troya abandoned Pb-Zn mine (The Basque Country, Northern Spain). Environ. Geol. 2000, 39, 800-806. [CrossRef]

12. Alberruche del Campo, E.; Arranz-González, J.C.; Rodríguez-Pacheco, R.; Vadillo-Fernández, L.; Rodríguez-Gómez, V.; Fernández-Naranjo, F.J. Manual para la Evaluación de Riesgos de Instalaciones de Residuos de Industrias Extractivas Cerradas o Abandonadas; Instituto Geológico y Minero de España-Ministerio de Agricultura, Alimentación y Medio Ambiente: Madrid, Spain, 2014; ISBN 978-84-7840-934-1.

13. Popovic, V.; Miljkovic, J.Ž.; Subic, J.; Jean-Vasile, A.; Adrian, N.; Nicolaescu, E. Sustainable land management in mining areas in Serbia and Romania. Sustainability 2015, 7, 11857-11877. [CrossRef]

14. Salomons, W.; Förstner, U.; Mader, P. (Eds.) Heavy Metals. Problems and Solutions; Springer: Berlin, Germany, 1995; ISBN 978-3-642-79316-5.

15. Pérez-Santana, S.; Pomares, A.M.; Villanueva, T.M.; Peña-Icart, M.; Brunori, C.; Morabito, R. Total and partial digestion of sediments for the evaluation of trace element environmental pollution. Chemosphere 2007, 66, 1545-1553. [CrossRef] [PubMed]

16. Zhang, L.; Liao, Q.; Shao, S.; Zhang, N.; Shen, Q.; Liu, C. Heavy Metal Pollution, Fractionation, and Potential Ecological Risks in Sediments from Lake Chaohu (Eastern China) and the Surrounding Rivers. Int. J. Environ. Res. Public Health 2015, 12, 14115-14131. [CrossRef] [PubMed]

17. Paustenbach, D.J. The practice of exposure assessment: A state of the art review. J. Toxicol. Environ. Health $B$ Crit. Rev. 2000, 3, 179-291. [CrossRef] [PubMed]

18. Christophoridis, C.; Dedepsidis, D.; Fytianos, K. Occurrence and distribution of selected heavy metals in the surface sediments of Thermaikos Gulf, N. of Greece. Assessment ussing pollution indicators. J. Hazard. Mater. 2009, 168, 1082-1091. [CrossRef] [PubMed]

19. Khan, M.Z.H.; Hasan, M.R.; Khan, M.; Aktar, S.; Fatema, K. Distribution of Heavy Metals in Surface Sediments of the Bay of Bengal Coast. J. Toxicol. 2017, 9235764. [CrossRef] [PubMed]

20. Borja, A.; Heinrich, H. Implementing the European Water Framework: The debate continues. Mar. Pollut. Bull. 2005, 50, 486-488. [CrossRef] [PubMed]

21. Díaz de Alba, M.; Galindo-Riaño, M.D.; Casanueva-Marenco, M.J.; García-Vargas, M.; Kosore, C.M. Assessment of the metal pollution, potential toxicity and speciation of sediments from Algeciras Bay (South Spain) using chemometric tools. J. Hazard. Mater. 2011, 190, 177-187. [CrossRef] [PubMed]

22. Zhou, H.; GuoSoil, X. Soil Heavy Metal Pollution Evaluation around Mine Area with Traditional and Ecological Assessment Methods. J. Geosci. Environ. Prot. 2015, 3, 28-33. [CrossRef]

23. Pellegrini, S.; García, G.; Peñas-Castejón, J.M.; Vignozzi, N.; Constantini, E.A.C. Pedogenesis in mine tails affects macroporisity, hydrological properties and pollutant flow. Catena 2016, 136, 3-16. [CrossRef]

24. Chen, X.; Zhou, J.; Chen, Q.; Shi, X.; Gou, Y. CFD Simulation of Pipeline Transport Properties of Mine Tailings Three-Phase Foam Slurry Backfill. Minerals 2017, 7, 149. [CrossRef]

25. Buzzi, J.; Riaza, A.; García-Meléndez, E.; Weide, S.; Bachmann, M. Mapping changes in a recovering mine site with hyper spectral airborne HyMap imagery (Sotiel, SW Spain). Minerals 2014, 4, 313-329. [CrossRef]

26. Pattelli, G.; Rimondi, V.; Benvenuti, M.; Chiarantini, L.; Colica, A.; Costagliola, P.; Di Benedetto, F.; Lattanzi, P.; Paolieri, M.; Rinaldi, M. Effects of the November 2012 flood event on the mobilization of $\mathrm{Hg}$ from the Mount Amiata mining district to the sediments of the Paglia River Basin. Minerals 2014, 4, 241-256. [CrossRef]

27. Lynch, S.F.L.; Batty, L.C.; Byrne, P. Environmental risk of metal mining contaminated river bank sediment at redox-transitional zones. Minerals 2014, 4, 52-73. [CrossRef] 
28. Nordstrom, D.K. Mine waters: Acidic to circumneutral. Elements 2011, 7, 393-398. [CrossRef]

29. Dold, B. Submarine tailings disposal (STD)—A review. Minerals 2014, 4, 642-666. [CrossRef]

30. Johnson, D.B. Recent developments in microbiological approaches for securing mine wastes and for recovering metals from mine waters. Minerals 2014, 4, 279-292. [CrossRef]

31. Huang, L.; Zhang, Y.; Guo, Y.; Zhu, D.; Porter, A.L. Four dimensional science and technology planning: A new approach based on bibliometrics and technology roadmapping. Technol. Forecast. Soc. Chang. 2014, 81, 39-48. [CrossRef]

32. Zhang, Y.; Zhang, Y.; Shi, K.; Yao, X. Research development, current hotspots, and future directions of water research based on MODIS images: A critical review with a bibliometric analysis. Environ. Sci. Pollut. Res. Int. 2017, 24, 15226-15239. [CrossRef] [PubMed]

33. Rodrigues-Vaz, C.; Shoeninger-Rauen, T.R.; Rojas-Lezana, A.G. Sustainability and innovation in the automotive sector: A structured content analysis. Sustainability 2017, 9, 880. [CrossRef]

34. Gusmão-Caiado, R.G.; de Freitas-Dias, R.; Veiga-Mattos, L.; Gonçalves-Quelhas, O.L.; Leal-Filho, W. Towards sustainable development through the perspective of eco-efficiency-A systematic literature review. J. Clean. Prod. 2017, 165, 890-904. [CrossRef]

35. Zhong, S.; Geng, Y.; Liu, W.; Gao, C.; Chen, W. A bibliometric review on natural resource accounting during 1995-2014. J. Clean. Prod. 2016, 139, 122-132. [CrossRef]

36. Li, W.; Zhao, Y. Bibliometric analysis of global environmental assessment research in a 20-year period. Environ. Impact Assess. Rev. 2015, 50, 158-166. [CrossRef]

37. Waltman, L.; van Eck, N.J.; Noyons, E.C. A unified approach to mapping and clustering of bibliometric networks. J. Informetr. 2010, 4, 629-635. [CrossRef]

38. Garfield, E. Citation Indexes for Science. Science 1955, 122, 108-111. [CrossRef] [PubMed]

39. Zhou, X.; Zhang, Y.; Porter, A.L.; Guo, Y.; Zhu, D. A patent analysis method to trace technology evolutionary pathways. Scientometrics 2014, 100, 705-721. [CrossRef]

40. Lee, S.; Lee, S.; Seol, H.; Park, Y. Using patent information for designing new product and technology: Keyword based technology roadmapping. R D Manag. 2008, 38, 169-188. [CrossRef]

41. Suominen, A.; Toivanen, H. Map of science with topic modeling: Comparison of unsupervised learning and human-assigned subject classification. J. Assoc. Inf. Sci. Technol. 2016, 67, 2464-2476. [CrossRef]

42. Zhang, Y.; Chen, H.; Lu, J.; Zhang, G. Detecting and predicting the topic change of Knowledge-based Systems: A topic-based bibliometric analysis from 1991 to 2016. Knowl.-Based Syst. 2017, 133, 255-268. [CrossRef]

43. Rafols, I.; Porter, A.L.; Leydesdorff, L. Science overlay maps: A new tool for research policy and library management. J. Am. Soc. Inf. Sci. Technol. 2010, 61, 1871-1887. [CrossRef]

44. Robinson, D.K.; Huang, L.; Guo, Y.; Porter, A.L. Forecasting Innovation Pathways (FIP) for new and emerging science and technologies. Technol. Forecast. Soc. Chang. 2013, 80, 267-285. [CrossRef]

45. Zhang, Y.; Zhang, G.; Zhu, D.; Lu, J. Science evolutionary pathways: Identifying and visualizing relationships for scientific topics. J. Assoc. Inf. Sci. Technol. 2017, 68, 1925-1939. [CrossRef]

46. Durieux, V.; Gevenois, P.A. Bibliometric Indicators: Quality Measurements of Scientific Publication. Radiology 2010, 255, 342. [CrossRef] [PubMed]

47. Garrido-Cárdenas, J.A.; Manzano-Agugliaro, F. The metagenomics worldwide research. Curr. Genet. 2017, 63, 819-829. [CrossRef] [PubMed]

48. Velasco-Muñoz, J.V.; Aznar-Sánchez, J.A.; Belmonte-Ureña, L.J.; Román-Sánchez, I.M. Sustainable water use in agriculture: A review of worldwide research. Sustainability 2018, 10, 1084. [CrossRef]

49. Salmerón-Manzano, E.; Manzano-Agugliaro, F. Worldwide scientific production indexed by Scopus on Labour Relations. Publications 2017, 5, 25. [CrossRef]

50. Mongeon, P.; Paul-Hus, A. The journal coverage of Web of Science and Scopus: A comparative analysis. Scientometrics 2016, 106, 213-228. [CrossRef]

51. Gavel, Y.; Iselid, L. Web of Science and Scopus: A journal title overlap study. Online Inf. Rev. 2008, 32, 8-21. [CrossRef]

52. Borrett, S.R.; Sheble, L.; Moody, J.; Anway, E.C. Bibliometric review of ecological network analysis: 2010-2016. Ecol. Model. 2018, 382, 63-82. [CrossRef]

53. Wildgaard, L. A comparison of 17 author-level bibliometric indicators for researchers in Astronomy, Environmental Science, Philosophy and Public Health in Web of Science and Google Scholar. Scientometrics 2015, 104, 873. [CrossRef] 
54. Ştirbu, S.; Thirion, P.; Schmitz, S.; Haesbroeck, G.; Greco, N. The Utility of Google Scholar When Searching Geographical Literature: Comparison With Three Commercial Bibliographic Databases. J. Acad. Librariansh. 2015, 41, 322-329. [CrossRef]

55. Judd, S.J. Membrane technology costs and me. Water Res. 2017, 122, 1-9. [CrossRef] [PubMed]

56. Feng, Y.; Zhu, Q.; Lai, K.H. Corporate social responsibility for supply chain management: A literature review and bibliometric analysis. J. Clean. Prod. 2017, 158, 296-307. [CrossRef]

57. Mugomeri, E.; Bekele, B.S.; Mafaesa, M.; Maibvise, C.H.; Tarirai, C.; Aiyuk, S.E. A 30-year bibliometric analysis of research coverage on HIV and AIDS in Lesotho. Health Res. Policy Syst. 2017, 15, 1-9. [CrossRef] [PubMed]

58. Mateo-Sanguino, T.J. 50 years of rovers for planetary exploration: A retrospective review for future directions. Robot. Auton. Syst. 2017, 94, 172-185. [CrossRef]

59. Kokol, P.; Blazun-Vosner, E.; Zeleznik, D. Clinical simulation in nursing: A bibliometric analysis after its tenth anniversary. Clin. Simul. Nurs. 2017, 13, 161-167. [CrossRef]

60. Velasco-Muñoz, J.V.; Aznar-Sánchez, J.A.; Belmonte-Ureña, L.J.; López-Serrano, M.J. Advances in water use efficiency in agriculture: A bibliometric analysis. Water 2018, 10, 377. [CrossRef]

61. Li, X.; Huang, L. Toward a new paradigm for tailings phytostabilization-Nature of the substrates, amendment options, and anthropogenic pedogenesis. Crit. Rev. Environ. Sci. Technol. 2015, 45, 813-839. [CrossRef]

62. Li, X.; You, F.; Bond, P.L.; Huang, L. Establishing microbial diversity and functions in weathered and neutral $\mathrm{Cu}-\mathrm{Pb}-\mathrm{Zn}$ tailings with native soil addition. Geoderma 2015, 247-248, 108-116. [CrossRef]

63. Qian, G.; Schumann, R.C.; Li, J.; Short, M.D.; Fan, R.; Li, Y.; Kawashina, N.; Zhou, Y.; Smart, R.S.C.; Gerson, A.R. Strategies for reduced acid and metalliferous drainage by pyrite surface passivation. Minerals 2017, 7, 42. [CrossRef]

64. Ogbughalu, O.T.; Gerson, A.R.; Qian, G.; Smart, R.S.C.; Schumann, R.C.; Kawashima, N.; Fan, R.; Li, J.; Short, M.D. Heterotrophic microbial stimulation through biosolids addition for enhanced acid mine drainage control. Minerals 2017, 7, 105. [CrossRef]

65. Ellis, D.V. Effect of mine tailings on the biodiversity of the sea bed: Example of the Island Copper Mine, Canada. Seas Millennium Environ. Eval. 2000, 3, 235-246.

66. Miler, M.; Gosar, M. Characteristics and potential environmental influences of mine waste in the area of the closed Mežica Pb-Zn mine (Slovenia). J. Geochem. Explor. 2012, 112, 152-160. [CrossRef]

67. Méndez-Ramírez, M.; Hernández, M.A.A. Distribución de Fe, Zn, Pb, Cu, Cd y As originada por residuos mineros y aguas residuales en un transecto del Río Taxco en Guerrero, México. Rev. Mex. Cienc. Geol. 2012, $29,450-462$.

68. Bansch, C.; Topp, W. Woodland soil in a reclaimed lignite open-cast mine: A sustainable improvement of soil quality? Verh. Ges. Okol. 1998, 29, 511-518.

69. Gatzweiler, R.; Jahn, S.; Neubert, G.; Paul, M. Cover design for radioactive and AMD-producing mine waste in the Ronneburg area, Eastern Thuringia. Waste Manag. 2001, 21, 175-184. [CrossRef]

70. Ghose, M.K. Restoration and revegetation strategies for degraded mine land for sustainable mine closure. Land Contam. Reclam. 2004, 12, 363-378. [CrossRef]

71. Elshorbagy, A.; Jutla, A.; Barbour, L.; Kells, J. System dynamics approach to assess the sustainability of reclamation of disturbed watersheds. Can. J. Civ. Eng. 2005, 32, 144-158. [CrossRef]

72. Bowen, C.K.; Schuman, G.E.; Olson, R.A.; Ingram, L.J. Influence of topsoil depth on plant and soil attributes of 24-year old reclaimed mined lands. Arid Land Res. Manag. 2005, 19, 267-284. [CrossRef]

73. Van Deventer, P.W.; Bloem, A.A.; Hattingh, J.M. Soil quality as a key success factors in sustainable rehabilitation of kimberlite mine waste. J. S. Afr. Inst. Min. Metall. 2008, 108, 131-137. Available online: http:/ / www.scielo.org.za/scielo.php?pid=S2225-62532008000300001\&script=sci_arttext\&tlng=en (accessed on 14 April 2018).

74. Maddocks, G.; Lin, C.; McConchie, D. Field scale remediation of mine wastes at an abandoned gold mine, Australia II: Effects on plant growth and groundwater. Environ. Geol. 2009, 57, 987. [CrossRef]

75. Lottermoser, B.G.; Glass, H.J.; Page, C.N. Sustainable natural remediation of abandoned tailings by metal-excluding heather (Calluna vulgaris) and gorse (Ulex europaeus), Carnon Valley, Cornwall, UK. Ecol. Eng. 2011, 37, 1249-1253. [CrossRef] 
76. Wu, X.; Chen, Y.; Hu, J.; Yang, J.; Zhang, G. Current status and remediation measures for the solid mine ecological environment in Beijing, China. Environ. Earth. Sci. 2011, 64, 1555. [CrossRef]

77. Pepper, I.L.; Zerzghi, H.G.; Bengson, S.A.; Iker, B.C.; Banerjee, M.J.; Brooks, J.P. Bacterial populations within copper mine tailings: Long-term effects of amendment with Class A biosolids. J. Appl. Microbiol. 2012, 113, 569-577. [CrossRef] [PubMed]

78. Melgar-Ramírez, R.; González, V.; Sánchez, J.A.; García, I. Effects of application of organic and inorganic wastes for restoration of sulphur-mine soil. Water Air Soil Pollut. 2012, 223, 6123-6131. [CrossRef]

79. Valente, T.; Gomes, P.; Pamplona, J.; de la Torre, M.L. Natural stabilization of mine waste-dumps-Evolution of the vegetation cover in distinctive geochemical and mineralogical environments. J. Geochem. Explor. 2012, 123, 152-161. [CrossRef]

80. Courtney, R. Mine tailings composition in a historic site: Implications for ecological restoration. Environ. Geochem. Health 2013, 35, 79-88. [CrossRef] [PubMed]

81. Bigot, M.; Guterres, J.; Rossato, L.; Pudmenzky, A.; Doley, D.; Whittaker, M.; Pillai-McGarry, U.; Schmidt, S. Metal-binding hydrogel particles alleviate soil toxicity and facilitate healthy plant establishment of the native metallophyte grass Astrebla lappacea in mine waste rock and tailings. J. Hazard. Mater. 2013, 248-249, 424-434. [CrossRef] [PubMed]

82. Adams, A.; Raman, A.; Hodgkins, D. How do the plants used in phytoremediation in constructed wetlands, a sustainable remediation strategy, perform in heavy-metal-contaminated mine sites? Water Environ. J. 2013, 27, 373-386. [CrossRef]

83. Sjöberg, V.; Karlsson, S.; Grandin, A.; Allard, B. Conditioning sulfidic mine waste for growth of Agrostis capillaris-impact on solution chemistry. Environ. Sci. Pollut. Res. 2014, 21, 6888. [CrossRef] [PubMed]

84. Naeth, M.A.; Wilkinson, S.R. Establishment of restoration trajectories for upland tundra communities on diamond mine wastes in the Canadian arctic. Restor. Ecol. 2014, 22, 534-543. [CrossRef]

85. Banning, N.C.; Sawada, Y.; Phillips, I.R.; Murphy, D.V. Amendment of bauxite residue sand can alleviate constraints to plant establishment and nutrient cycling capacity in a water-limited environment. Ecol. Eng. 2014, 62, 179-187. [CrossRef]

86. Johansson, C.L.; Paul, N.A.; de Nys, R.; Roberts, D.A. The complexity of biosorption treatments for oxyanions in a multi-element mine effluent. J. Environ. Manag. 2015, 151, 386-392. [CrossRef] [PubMed]

87. Li, J.J.; Yan, J.X.; Li, H.J. Effects of different reclaimed measures on soil carbon mineralization and enzyme actives in mining areas. Acta Ecol. Sin. 2015, 35, 4178-4185. [CrossRef]

88. Anawar, H.M. Sustainable rehabilitation of mining waste and acid mine drainage using geochemistry, mine type, mineralogy, texture, ore extraction and climate knowledge. J. Environ. Manag. 2015, 158, 111-121. [CrossRef] [PubMed]

89. Santini, T.C.; Banning, N.C. Alkaline tailings as novel soil forming substrates: Reframing perspectives on mining and refining wastes. Hydrometallurgy 2016, 164, 38-47. [CrossRef]

90. Nirola, R.; Megharaj, M.; Beecham, S.; Aryal, R.; Thavamani, P.; Vankateswarlu, K.; Saint, C. Remediation of metalliferous mines, revegetation challenges and emerging prospects in semi-arid and arid conditions. Environ. Sci. Pollut. Res. 2016, 23, 20131-20150. [CrossRef] [PubMed]

91. Párraga-Aguado, I.; González-Alcaraz, M.N.; López-Orenes, A.; Ferrer-Ayala, M.A.; Conesa, H.M. Evaluation of the environmental plasticity in the xerohalophyte Zygophyllum fabago L. for the phytomanagement of mine tailings in semiarid areas. Chemosphere 2016, 161, 259-265. [CrossRef] [PubMed]

92. Nancucheo, I.; Bitencourt, J.A.P.; Sahoo, P.K.; Oliveira-Alves, J.; Siqueira, J.O.; Oliveira, G. Recent Developments for Remediating Acidic Mine Waters Using Sulfidogenic Bacteria. BioMed Res. Int. 2017, 2017, 7256582. [CrossRef] [PubMed]

93. Plaza, F.; Wen, Y.; Perone, H.; Xu, Y.; Liang, X. Acid rock drainage passive remediation: Potential use of alkaline clay, optimal mixing ratio and long-term impacts. Sci. Total Environ. 2017, 576, 572-585. [CrossRef] [PubMed]

94. Sözen, S.; Orhon, D.; Dinçer, H.; Ateşok, G.; Baştürkçü, H.; Yalçın, T.; Öznesil, H.; Karaca, C.; Allı, B.; Dulkadiroğlu, H.; et al. Resource recovery as a sustainable perspective for the remediation of mining wastes: Rehabilitation of the CMC mining waste site in Northern Cyprus. Bull. Eng. Geol. Environ. 2017, 76, 1535-1547. [CrossRef] 
95. Mwandira, W.; Nakashima, K.; Kawasaki, S. Bioremediation of lead-contaminated mine waste by Pararhodobacter sp. based on the microbially induced calcium carbonate precipitation technique and its effects on strength of coarse and fine grained sand. Ecol. Eng. 2017, 109, 57-64. [CrossRef]

96. Bartke, K. Waste management in the mineral recovery industry according to EU guideline 2006/21/EC. Wasser Abfall 2009, 11, 40-44.

97. Kalin, M. Passive mine water treatment: The correct approach? Ecol. Eng. 2004, 22, 299-304. [CrossRef]

98. Azam, S. Thickening of mine waste slurries. Geotech. News 2004, 22, 40-43.

99. Younger, P.L. Environmental impacts of coal mining and associated wastes: A geochemical perspective. Geol. Soc. Lond. 2004, 236, 169-209. [CrossRef]

100. Macklin, M.G.; Brewer, P.A.; Hudson-Edwards, K.A.; Bird, G.; Coulthard, T.J.; Dennis, I.A.; Lechler, P.J.; Miller, J.R.; Turner, J.N. A geomorphological approach to the management of rivers contaminated by metal mining. Geomorphology 2006, 79, 423-447. [CrossRef]

101. Meech, J.A.; Scoble, M.; Wilson, W.; Lang, B.; Klein, B.; Veiga, M.M.; Hall, R.; Ghomshei, M.; Baldwin, S.; Lavkulich, L.M.; et al. CERM3 and its contribution to providing sustainable research for the mining industry. CIM Bull. 2003, 96, 72-81.

102. Careddu, N.; Siotto, G.; Siotto, R.; Tilocca, C. From landfill to water, land and life: The creation of the Centre for stone materials aimed at secondary processing. Resour. Policy 2013, 38, 258-265. [CrossRef]

103. Shukla, M.K.; Lal, R. Soil organic carbon stock for reclaimed minesoils in northeastern Ohio. Land Degrad. Dev. 2005, 16, 377-386. [CrossRef]

104. Wajima, T.; Ikegami, Y. Stabilization of mine waste using paper sludge ash under laboratory condition. J. Jpn. Inst. Met. 2008, 72, 903-910. [CrossRef]

105. Hwang, T.; Neculita, C.M.; Han, J.I. Biosulfides precipitation in weathered tailings amended with food waste-based compost and zeolite. J. Environ. Qual. 2012, 41, 1857-1864. [CrossRef] [PubMed]

106. Emery, J.J.; MacKay, M.H.; Umar, P.A.; Vanderveer, D.G.; Pichette, R.J. Use of wastes and byproducts as pavement construction materials. In Proceedings of the Canadian Geotechnical Conference, Toronto, ON, Canada, 25-28 October 1992; pp. 45/1-45/10.

107. Venkatarama-Reddy, B.V. Sustainable building technologies. Curr. Sci. 2004, 87, 899-907.

108. Gabzdyl, W.; Hanak, B. Raw materials from the Upper Silesia Coal Basin and from the adjacent areas. Prz. Geol. 2005, 53, 726-733.

109. Arrigo, I.; Catalfamo, P.; Cavallari, L.; Di Pasquale, S. Use of zeolitized pumice waste as a water softening agent. J. Hazard. Mater. 2007, 147, 513-517. [CrossRef] [PubMed]

110. Liu, H.; Liu, Z. Recycling utilization patterns of coal mining waste in China. Resour. Conserv. Recycl. 2010, 54, 1331-1340. [CrossRef]

111. Lottermoser, B.G. Recycling, reuse and rehabilitation of mine wastes. Elements 2011, 7, 405-410. [CrossRef]

112. Cadierno, J.F.; Romero, M.I.G.; Valdés, A.J.; Morán del Pozo, J.M.; García-González, J.; Robles, D.R.; Espinosa, J.V. Characterization of Colliery Spoils in León: Potential Uses in Rural Infrastructures. Geotech. Geol. Eng. 2014, 32, 439-452. [CrossRef]

113. Kundu, S.; Aggarwal, A.; Mazumdar, S.; Dutt, K.B. Stabilization characteristics of copper mine tailings through its utilization as a partial substitute for cement in concrete: Preliminary investigations. Environ. Earth Sci. 2016, 75, 227. [CrossRef]

114. Yang, Y.; Chen, T.; Morrison, L.; Gerrity, S.; Collins, G.; Porca, E.; Li, R.; Zhan, X. Nanostructured pyrrhotite supports autotrophic denitrification for simultaneous nitrogen and phosphorus removal from secondary effluents. Chem. Eng. J. 2017, 328, 511-518. [CrossRef]

115. Rana, A.; Kalla, P.; Csetenyi, L.J. Recycling of dimension limestone industry waste in concrete. Int. J. Min. Reclam. Environ. 2017, 31, 231-250. [CrossRef]

116. Taha, Y.; Benzaazoua, M.; Hakkou, R.; Mansori, M. Coal mine wastes recycling for coal recovery and eco-friendly bricks production. Miner. Eng. 2017, 107, 123-138. [CrossRef]

117. Gorakhki, M.H.; Bareither, C.A. Sustainable reuse of mine tailings and waste rock as water-balance covers. Minerals 2017, 7, 128. [CrossRef]

(C) 2018 by the authors. Licensee MDPI, Basel, Switzerland. This article is an open access article distributed under the terms and conditions of the Creative Commons Attribution (CC BY) license (http://creativecommons.org/licenses/by/4.0/). 